Florida International University FIU Digital Commons

3-30-2016

\title{
Epistemological Analysis of Traditionalist and Reformist Discourses Pertaining to Islamic Feminism in Iran
}

Meisam Vahedi

Florida International University, meisam_va@yahoo.com

DOI: $10.25148 /$ etd.FIDC000277

Follow this and additional works at: https://digitalcommons.fiu.edu/etd

Part of the Women's Studies Commons

\section{Recommended Citation}

Vahedi, Meisam, "Epistemological Analysis of Traditionalist and Reformist Discourses Pertaining to Islamic Feminism in Iran" (2016). FIU Electronic Theses and Dissertations. 2446.

https://digitalcommons.fiu.edu/etd/2446 


\title{
FLORIDA INTERNATIONAL UNIVERSITY
}

Miami, Florida

\section{EPISTEMOLOGICAL ANALYSIS OF TRADITIONALIST AND REFORMIST DISCOURSES PERTAINING TO ISLAMIC FEMINISM IN IRAN}

\author{
A thesis submitted in partial fulfillment of the \\ requirements for the degree of \\ MASTER OF ARTS \\ in \\ RELIGIOUS STUDIES \\ by \\ Meisam Vahedi
}


To: Dean John Stack

Steven J. Green School of International and Public Affairs

This thesis, written by Meisam Vahedi, and entitled Epistemological Analysis of Traditionalist and Reformist Discourses Pertaining to Islamic Feminism in Iran, having been approved in respect to style and intellectual content, is referred to you for judgment.

We have read this thesis and recommend that it be approved.

Albert Wuaku

$\begin{array}{r}\text { Erik Larson } \\ \hline \text { Iqbal Akhtar, Major Professor }\end{array}$

Date of Defense: March 30, 2016

The thesis of Meisam Vahedi is approved.

Dean John Stack

Steven J. Green School of International and Public Affairs

Andrés G. Gil

Vice President for Research and Economic Development and Dean of the University Graduate School

Florida International University, 2016 


\section{DEDICATION}

I dedicate this thesis to my parents. Without their patience, understanding, support, and most of all love, the completion of this work would not have been possible. 


\section{ACKNOWLEDGMENTS}

I wish to thank the members of my committee for their support, patience, and good humor. Their gentle but firm direction has been most appreciated. Dr. Wuaku, and Dr. Larson were particularly helpful in guiding me toward the completion of this research. Finally, I would like to thank my major professor, Dr. Iqbal Akhtar. From the beginning, he had confidence in my abilities to not only complete a degree, but to complete it with excellence.

I have found my coursework throughout the Curriculum and Instruction program to be stimulating and thoughtful, providing me with the tools with which to explore both past and present ideas and issues. 
ABSTACT OF THE THESIS

EPISTEMOLOGICAL ANALYSIS OF TRADITIONALIST AND REFORMIST

DISCOURSES PERTAINING TO ISLAMIC FEMINISM IN IRAN

\author{
by
}

Meisam Vahedi

Florida International University, 2016

Miami, Florida

\title{
Professor Iqbal Akhtar, Major Professor
}

Islamic feminism in Iran is defined as the radical rethinking of religious and sacred texts from a feminist perspective. The purpose of this research is to show how an Islamic feminist discourse developed in Iran, and to outline the differences between the reformist and traditionalist epistemological foundations of women's rights discourse in Iran.

This study, using documentary research methods, demonstrates that central to the development of Islamic feminism is the development of the reformist movement in Iran. Moreover, it is shown that the main impedance to women's equality in Iran is the traditionalist epistemology in religious law. While reformists believe that employing justice in Islamic law requires absolute equality regarding both men and women’s rights, traditionalists present a different interpretation of the notion of justice. According to the traditionalist discourse, since men and women have natural and inborn differences, two separate kinds of law are needed to regulate their lives. 


\section{TABLE OF CONTENTS}

CHAPTER

PAGE

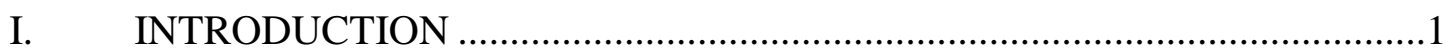

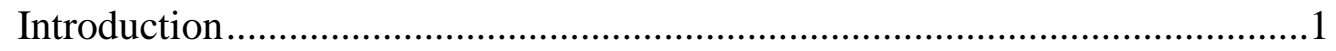

Significance and Importance.....................................................................6

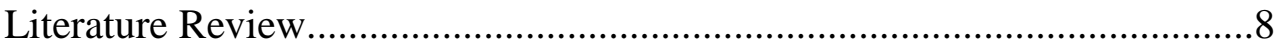

Feminist Movements in Iran ...................................................................

Islamic Feminism in the Middle East ......................................................

Islamic Feminism in Iran ............................................................10

Influential Factors in Developing Islamic Feminism in Iran ..................11

Reformist Discourse...........................................................................12

Traditionalist Discourse ................................................................13

Neo-traditionalist Discourse ............................................................14

Definition of Women's rights and Gender Roles in Traditionalist.........15

Discourse

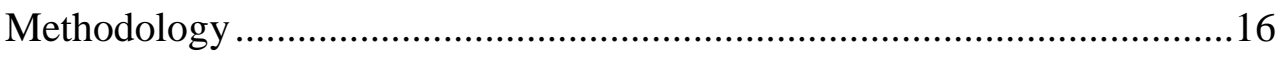

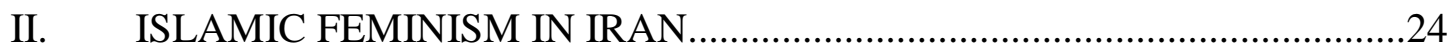

Feminist Movements in Iran ......................................................................24

Islamic Feminism in the Middle East .........................................................27

Islamic Feminism in Iran ...............................................................................

Influential Factors in Developing Islamic Feminism in Iran .........................33

III. MAIN DISCOURSES PERTAINING TO ISLAMIC FEMINISM ..................38 IN IRAN

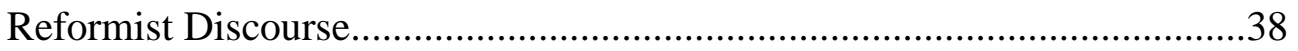

Traditionalist Discourse ...............................................................................4

Neo-traditionalist Discourse .........................................................................51

Definition of Women's rights and Gender Roles in Traditionalist.................55

Discourse

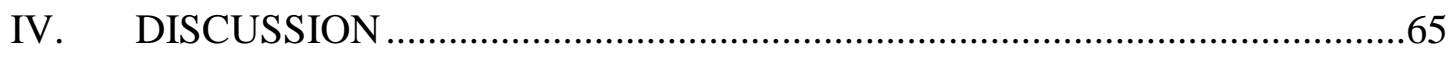

Discussion and Conclusion.......................................................................65

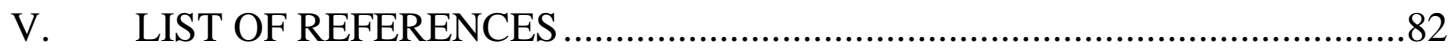




\section{CHAPTER I: INTRODUCTION}

Introduction:

After the Islamic revolution in 1979 in Iran, a religious government took control over Iranian society. The Islamic republic of Iran ordained a set of Islamic laws and compelled people to obey an official interpretation of Islam, which was announced by clergies at the highest powerful position in the political structure of Iran. This official monolithic interpretation of Islamic texts has put Iranian women in a difficult situation, as they have been deprived of some parts of their citizen rights and have been confronted with limitations regarding their presence in public places.

In recent decades, Iranian secular activists, mostly living in Western countries, have tried to build support for Iranian women's rights. They have tried to regain rights for women lost through the re-Islamization policies of the Islamic government in Iran. Although these activities were slightly successful in publicizing Iranian women's circumstances to the world, they could not achieve adequate success in bringing freedom for women and restoring their rights inside Iran (Ahmadi 2006). The main reason for these unsuccessful attempts is that the Islamic Republic of Iran has labeled secular discourses as anti-Islamic discourses, and hence has prevented their development in Iranian religious culture. Moreover, like other Islamic countries in the Middle East, secular discourses could not be accepted by the majority of the Iranian population, who are Muslims and follow their rights within Islamic discourse. Hence, it seems that a religious movement from inside the country was needed to change the dominant discourse presented by the government and help Iranian women attain their rights as full citizens. This movement has started in recent 
decades in Iran, with the purpose of reinterpreting religious sources from a nontraditionalist perspective and presenting an egalitarian interpretation of Islamic scriptures.

Iranian Muslim feminists have presented their feminist discourse within an Islamic context. However, their interpretation of religious and sacred texts on women's issues is different from that of official clergies. Muslim feminists have demanded alterations in the traditional interpretation of sacred texts and consequently modifications to Islamic laws extracted from religious sources. Traditional jurists, who were responsible for extracting Islamic law from sacred texts and held absolute power over state institutions, did not tolerate any reformist voices outside of dominant traditionalist discourse. With the expansion of feminist activism, Muslim feminists have been confronted with problems imposed by the Iranian government as the main supporter of traditionalist discourse of Islam. These problems have caused social and political burden for feminist activists, as well as academic scholars (Najmabadi 1995). Thousands of women put their lives, their careers, and their families in danger fighting for recognition as full citizens and restoring their human rights (Ahmadi 2006). In this political condition, some other feminists preferred to leave the country and choose a lonely life in exile rather than living under the rules of the Islamic Republic.

However, unlike the existing problems, and barriers that were put in the way of feminist activists by the Islamic government, Iranian Muslim feminists could exhibit admirable resistance against governmental pressures. They could develop a new discourse on feminism and Islam, challenging dominant fundamental discourse supported by traditional jurists. As a result of their endeavors, Islamic feminism, as a movement, has increasingly 
become mainstream in Iran. Islamic feminism is defined here as the radical rethinking of religious and sacred texts from a feminist perspective. Reformist and feminist thinkers in Iran have tried to present a new interpretation of sacred texts in order to combat repressive policies and to advocate for equal legal rights. This new approach includes not only reinterpretation of fiqh (Islamic jurisprudence), but also reinterpretation of shari'a ${ }^{1}$ (Maqasid al-shari'a) as the principal foundation of Islamic law. This movement of reinterpreting Islamic principles from a feminist perspective was so unprecedented in the Islamic world that it led Ziba Mir-Hosseini to remark, "The doors opened to a new interpretation and new thinking of religious and sacred texts in Iran, in a new scale that is unparalleled in the history of Islamic law” (Mir-Hosseini 1996: 12).

Various political, economic, and social factors have influenced the development of Islamic feminism in Iran. The processes of globalization have brought awareness of various political interpretations of women's rights discourses around the world and helped women to rethink their own society's policies and norms (Tohidi 2002: 1). The processes of globalization have linked the Iranian situation to a global struggle for freedom based on a gender rights discourse emerging from Western societies. In particular, postmodernism has helped Iranian Muslim feminists rethink gendered Islam (Ahmadi 2006). Notwithstanding the impact of Western feminism on the Iranian discourses, central to the development of Islamic feminism is the development of the reformist movement in Iran. Iranian reformism

\footnotetext{
1 "The shari' $a$ in its popular usage indicated the religion of Islam, God`s true religion as it embodies revelation in praxis" (Sachedina 1999a: 15). Therefore, it is perceived as a part of revelation (wahy); while, fiqh is a part of religious science whose aim is to recognize and bring out shari'a legal rules from Islamic sacred sources: the Qur'an and Sunna. Fiqh is a legal science with its own methodology and legal theories (usul-al fiqh theories); this science was developed by fuqaha' during the centuries in dialogue with other religious and non-religious sciences. In other words, shari' $a$ is sacred and eternal while figh is a human science and subject to change.
} 
aims not only to review Islamic laws regarding various aspects of human life (including women's issues), but also to challenge the philosophical foundation of these laws from a modern and postmodern perspective. From this foundation, the women's movement can be categorized within the reformist movement, which began in late nineteenth century Iran (Mir-Hosseini 2002; Tohidi 2006).

The objective of Iranian Islamist feminism is the pursuit of equality and justice in Islamic law on gender issues (Lorestani 2003). Iranian Islamist feminists challenge traditional jurists by presenting new discourses underlying Islamic legal thought. These discourses can be divided into two types: neo-traditionalist and reformist. While neo-traditionalist discourse was almost successful in restoring women's rights, the greater possibility for greater women's rights in Iran is more likely through the language of reformism (MirHosseini 2001). Reformist discourse, in contrast to neo-traditionalist discourse, sees women's sexuality as regulated by social circumstances and not by Divine will. Reformist discourse claims gender inequality embedded in Islamic laws as a societal construction by male jurists that is neither sacred nor fixed, and rather is human and subject to contestation.

Both reformist and traditional thinkers believe that Islam is a religion of fairness and justice. They both see in the shari' $a$ equality for both genders, however they reach different conclusions in applying Islamic laws from the shari'a. The tension between these two groups in interpreting the shari' $a$ is a matter of perspective with regards to a discourse of rights. Do humans have inalienable rights or are rights mutually reciprocal communitarian duties? Reformists speak of "human rights," while traditionalists speak of "human duties". Also, while reformists believe that employing fairness and justice in Islamic laws requires 
absolute equality regarding both men and women's rights, traditionalists present a different interpretation of the notion of justice. They believe that Islamic law is fair toward both genders, but this fairness does not mean proportional equality. From a biological perspective, women and men have some natural and inborn differences that demand different considerations regarding their rights and duties. Because men and women are different, two separate kinds of laws are needed to regulate their lives. Only by acknowledging these biological differences can true justice toward women be achieved. Reformism seeks to further develop this line of thinking to advocate for women's rights rather than challenging this epistemology with the introduction of an antithetical Western rights discourse.

This research will focus on epistemological and philosophical foundations of the reformist and traditional discourses underlying Islamic legal thought in Iran. The two main questions my research will answer are:

How has an Islamic feminist discourse in Iran developed from the reformist movement?

What are the epistemological foundations of traditional and reformist discourses regarding women's issues and gender rights?

This research is organized into four chapters. The first chapter will cover the introduction, significance and importance of the study, methodology, and literature review. The second chapter will present a review of Islamic feminism in Iran and other Islamic countries. Also, it will discuss the influences of various factors, including reformist ideas, on the development of Islamic feminism in Iran. The third chapter will include reformist, neo- 
traditionalist, and traditionalist interpretations of women's issues. It will also discuss recent updates in traditionalist discourse on women's rights. The forth chapter will examine the issue of justice, gender roles, and women's rights in both reformist and traditionalist epistemologies. Moreover, it will discuss the differences of philosophy and epistemology of traditionalist and reformist discourses in interpreting religious texts and sacred sources.

Significance and Importance:

The main reasons for traditional interpretation of Islamic legal thought on women's rights in Iran can be classified into three categories: ideological, political and epistemological. The ideological perspective focuses on the patriarchal structure of Islamic law. The political perspective focuses on the exclusion of women in the process of interpreting religious texts. The epistemological perspective questions the traditional assumptions underlying the interpretation of shari' $a$ and fiqh. Patriarchy has certainly influenced jurists' worldview in their interpretation of religious texts. This has excluded women from the processes of interpreting Islamic law. Recently, however, globalization has interconnected global discourses on gender rights and women's issues. The consequences of this will be profound on the development women's rights Iran. Already, we are seeing an increasing presence of women in educational, political and social structures of Iran in recent decades. The number of women in higher education has increased dramatically in recent years (Bahrami and Etemadi 2013). In recent years, there has been an increase in women entering the Iranian workforce (Ibid). From 2006 to 2011, we witnessed a 6 percent increase in the number of female employees in both governmental and private companies (Khosroshahi 2014). Moreover, women have demonstrated great interest in working in women-oriented, 
non-governmental organizations (NGOs). In this regard, the number of NGOs run by women has significantly increased within the last decades². In tandem, there have been reformist endeavors in the Iranian parliament to legislate laws in order to improve women's conditions within the family and provide employment protections (Mir-Hosseini 2002). Indeed, past decades observed a flourishing progress in women's social, cultural and intellectual productions in Iran. After the Islamic revolution of Iran, in contrast to the deepest fear of the Islamic government from the activities of secular feminists, women not only were not disappeared from public places, but also they could achieve much success in their private and public lives; women had a considerable presence in educational and industrial organizations, artistic creations, professional occupations and even sports activities (Najmabadi 1995: 52).

Therefore, it seems that increasing the visible presence of women in social and political life will eventually erode the patriarchal legal structure and empower women through progressive legislation.

Despite social and political gains for Iranian women in recent years, the main impedance to women's equality is traditionalist epistemology in religious law. Women are still excluded from interpreting religious and sacred sources. The development of Islamic law is still controlled by traditional jurists, despite reformist gains in recent years. Traditional jurists have made modifications in some parts of Islamic law concerning women's rights in recent decades. However, the majority of Islamic laws on gender rights and women's

\footnotetext{
${ }^{2}$ For further review, see "Zanane tarikhe moasere Iran dar chahardahe akhir, ghesmate dovom" (Iranian Women in Recent four decades, Part two), Pegah Houzeh, 07/26/2008, http://www.hawzah.net/fa/Magazine
} 
issues has remained unchanged. Indeed, the conflict between reformists and traditionalists is based upon a fundamental difference of the underlying philosophy of women's role based on the conceptions of rights and duties and corresponding notions of justice and equality. Significant progress in changing Islamic law regarding women's issues and gender rights will not be achieved until the foundation of traditionalist discourses is challenged. In summary, this research will outline the duality of reformist and traditionalist epistemological foundations of women's rights discourses in Iran.

Literature Review:

Feminist Movements in Iran:

Feminist activism in Iran is classified into two major groups: secular and Islamic. Because of political pressure in Iran in the early years of Islamic revolution, feminist activism was mostly restricted to the activities of secular women outside of Iran. Najmabadi (1995), Moghisi (1999), and Ahmadi (2006) describe the suffering conditions for women after the Islamic revolution in Iran. Najmabadi (1995) calls those years, “yeas of hardship, years of growth.”

While secular activists in and outside of Iran have tried to regain women's political and social rights, as well as draw the attention of the international world to the suffering situation of Iranian women, they could not achieve adequate success in bringing freedom for women inside Iran as an Islamic country. Ahmadi (2006) refers to the reasons for the secular activists' lack of success in restoring women's rights in Iran. 
On the other hand, the Islamic feminist movement could achieve more success than the secular feminist movement in bringing freedom for women in Iran. Iranian Muslim women have accepted Islamic feminist discourse as an authenticate source for expressing their political and social demands, as well as for requesting equal rights in Islamic jurisprudence. Muslim feminists have tried to oppose the clergy's monolithic readership of Islam; they have challenged the traditional interpretation of Islamic theological and legal sources to present a new tendency in Islamic feminism. Ahmadi (2006) and Najmabadi (1995) describe the process of the development of Islamic feminism in the past decades in Iran. Mir-Hosseini $(1996,1998,2003)$ mostly mentions the philosophical foundations of Islamic feminist discourse, which was supported by traditional jurists at the top of the political hierarchy Iran, and their conflict with traditionalist discourse. She also describes the similarities between reformist discourse and Islamic feminist discourse, as well as the major differences between reformists and traditionalists in their interpretation of Islamic law regarding gender roles and women’s issues.

Islamic Feminism in the Middle East:

Islamic feminism is not only restricted to Iran. We can witness the development of feminist movements in other Islamic countries in the Middle East. Karam (2011: 202) classifies feminist movements in the Middle East and Arab countries into three streams in a continuum: secular, religious, and Islamic. She describes the characteristics of these three movements in the Arab World and their relation to one another. She mentions that barely, in the Middle East and Arab World, is there any admiration and verification from religious circles for those working outside of these circles, like secular activists. Indeed, secular and 
religious feminist movements had less success in restoring women's rights in Arab countries in comparison with the Islamic feminist movement.

Mehrangiz Kar (1993) discusses that like other Islamic countries in the Middle East, the feminist movement was a very marginal issue among followers of religions other than Islam. Also, the secular feminist movement in Iran could not attain more success in bringing freedom for women. Islamic feminism was the most powerful means to advocating for women's rights in Iran, which was the same as in other Islamic countries. However, Islamic feminism in Iran has considerable differences from Islamic feminism in the Arab World. Mir-Hosseini (1996, 2003) refers to these differences between Muslim feminists in Iran and other Islamic countries in their interpretation of religious texts and extracting Islamic law from sacred sources.

Islamic feminism in Iran:

Bardan (2002) provides a general definition of Islamic feminism, and Moghissi (1999) mentions various characteristics of Islamic feminism in Islamic countries. Mir-Hosseini (1996) and Esposito (1998) talk about differences between Islamic feminism in Iran and other Islamic countries. They say that Muslim feminists in Iran demanded not only the rethinking of Islamic legal sources, but also the reinterpretation of sacred texts from a feminist perspective. To develop their feminist discourse, Iranian Muslim women applied their life experiences as women to their interpretation of sacred texts, as well as their independent research in various religious sources. Ahmadi (2006) and Bardan (2002) mention the main methodologies used by Iranian Muslim women in developing Islamic feminist discourse in Iran. 
Influential Factors in Developing Islamic Feminism in Iran:

We can classify various factors that influenced the development of Islamic feminism in Iran into three main groups: the reformist movement, postmodern theories, and the globalization of women's struggle for freedom. Mir-Hosseini (1996) and Tohidi (2006) discuss how Iranian Muslim feminists employed reformist ideas in their discussion of women's rights and gender roles in Islam. They believe that Islamic feminist discourse in Iran has actually emerged from within the reformist discourse.

Amir Arjomand (2004) and Ahmadi (2006) talk about the influences of postmodern theories on the development of Islamic feminism in Iran. Amir Arjomand believes that the Islamic feminist movement in Iran is a modern movement using modern and postmodern ideas in its discourse. Ahmadi provides examples of using postmodern conceptual tools by Iranian Muslim feminists in their discussion of women's issues in Islam. For instance, through employing postmodern critiques of language in their discussion, Iranian Muslim feminists could unveil the role of Arabic language in maintaining a gender-biased interpretation of sacred sources.

In addition to the reformist movement and postmodern ideas, the globalization of women's challenges for equality and justice paved the way for Iranian Muslim feminists to develop their own feminist discourse. Awareness of various interpretations of women's rights brought on by the processes of globalization for Iranian Muslim feminists has helped them to rethink their own society's policies and norms. Tohidi (2006) discusses how the processes of globalization made Iranian feminists familiar with feminist movements in Western and Islamic countries. 


\section{Reformist Discourse:}

Islamic feminist discourse in Iran can be classified as a part of the reformist discourse. New interpretations of sacred texts from a modern perspective, which was presented by Iranian Muslim reformers, paved the way for Iranian Muslim feminists to demand reformulating Islamic laws on women's issues from a feminist perspective.

While most of reformist intellectuals in Iran have not subscribed to the gender equality discourse, their reformist theories on the interpretation of sacred texts and Islamic knowledge have enabled Iranian religious women to attune their faith with their feminist ideas.

Iranian reformists have gathered at the Kiyan Institute, an intellectual and cultural institute in Tehran, around Abdolkarinm Soroush. Soroush’s reformist theories stimulated Iranian Muslim feminists to discuss of women's rights in Islam and propose the necessity of reinterpreting sacred texts from a feminist perspective. Indeed, among various reformist ideas, Soroush's theories had the most influence on shaping Iranian feminist discourse. One of his most influential ideas on shaping Iranian Islamic feminism was his discussion about the meaning of essential and accidental in Islam. Soroush $(1989,1999)$ separates essential parts of the Qur'an, which are unchangeable and everlasting, from accidentals, which are subject to change and contestation. He confirms that essential parts of sacred texts include the core message of religion, while accidentals are the events that have taken place in the history of Islam. These historical events must not be taken as the spirit of Islam. Soroush (1995, 2000) believes that we should pay attention to the historical and contextual background of the Qur'an in our interpretation of sharia' and Islamic law. 
In another reformist theory, known as the "expansion of Prophetic experience," Soroush (1999) describes how the prophet’s disciples expanded his religious experience in the history and developed Islamic knowledge. He argues that the Islamic knowledge expanded by the prophet's disciples must also be taken into account as the main sources of Islamic law. Hence, Islamic laws are not immutable, since they are not only based on what was stated in the Qur'an and Sunna.

Other reformers, like Alavitabar (2003) and Amirarjomand (2002), expand Soroush's theory about the accidentals of history to a vast degree, which covers most parts of sacred texts. Hence, they believe majority of sacred texts are to be reinterpreted from a modern perspective in order to be employed to the present time.

\section{Traditionalist Discourse:}

Traditionalist discourse was developed by jurists on the basis of the biological differences between men and women. In this discourse, gender inequality is taken for granted. Women's rights have no place in traditionalist discourse and gender relations are based on women's duties. Mir-Hosseini (2003) declares that, in traditionalist discourse, women are seen as sexual beings, not as social beings; the only domain in traditionalist discourse in which women's rights are partly discussed is the family law. She talks about gender-biased assumptions underlying traditionalist discourse, as well as the traditional interpretation of family laws proposed by jurists in Iran.

Also, traditionalist discourse reflects social and cultural circumstances of the society in which traditional jurists had lived. The patriarchal structure in that society shaped the 
worldview of classical jurists in their understanding of sacred texts. Ahmed (1992) and Mernissi (1991) discuss the influences of the patriarchal structure on the thinking modes of classical jurists.

The ideas of Ayatollah Makarem Shirazi are a representative of traditionalist discourse in contemporary Iran. His opinions are in line with the policies of the Islamic Republic of Iran on women's rights and gender roles. Moreover, present traditional jurists usually refer to his theories in their discussions on women's issues. His interpretation of gender relations and women’s rights in Islam has been published in Tahura magazine (2008).

Neo-traditionalist Discourse:

Another discourse underlying Islamic legal thought in Iran is the neo-traditionalist, or modern, discourse. Neo-traditional jurists tried to find a solution for modern problems that emerged in Islamic countries because of the changed status of women.

Mir-Hosseini (1999) and Siddiqi (1952) discuss how neo-traditionalists tried to resist against the emergence of Western values in Islamic countries, as well as support for gender equality in Islamic law. In this regard, Mir-Hosseini (2003) explains how neotraditionalists changed the gender-biased assumptions and theories underlying classical fiqh texts.

The theories of complementarity of gender rights and duties and the naturalness of shari'a law, which was first proposed by Ayatollah Murtaza Mutahhari (1991), has been used by jurists as the main foundation of neo-traditionalist discourse. In this regard, Mutahhari's interpretation of women's rights, which was developed in his book, The System of Women's 
rights in Islam (1991), is representative of the interpretation of women's rights in neotraditionalist discourse.

Definition of Women’s rights and Gender Roles in Traditionalist Discourse:

While traditional jurists changed the form of some parts of fiqh rules on gender issues, they have mostly remained faithful to the classical interpretation of fiqh texts. Not only have neo-traditional jurists followed Mutahhari’s ideas (1991) on women’s rights in Islam, but also traditional jurists applied his theories in their arguments for gender roles and women's rights in Islam.

The ideas of Ayatollah Makarem Shirazi are a representative of traditionalist discourse in contemporary Iran. His interpretation of gender relations and women's rights in Islam has been published in Tahura magazine (2008). He provides a rationalization for the traditional interpretation of classical fiqh texts. He explains the meaning of rights and duties in Islam. Moreover, he describes various conditions and circumstances under which an Islamic law on gender issues can be modified. Indeed, traditionalist discourse mostly remained faithful to the gender-biased assumptions underlying Islamic legal thought. Traditional jurists focused on the literal meaning of sacred texts, and did not consider the meaning of contexts in their interpretation of religious sources.

However, as mentioned before, neo-traditionalist discourse changed the gender-biased assumptions underlying classical fiqh texts, and adopted the theory of naturalness of shari'a law. Neo-traditionalists employed the findings of human sciences in their interpretation of religious sources, although their usage of modern theories in their analysis 
of gender relations was selective. Reformist discourse, in contrast to traditionalist and neotraditionalist discourse, did not rely on the literal meaning of verses in sacred texts, and adopted a contextual and historical interpretation of religious sources. Reformers used hermeneutic approach in their analysis of sacred texts. They did not accept gender-biased assumptions underlying classical fiqh texts as valid and reliable assumptions. Also, their usage of modern theories, in their discussions for women's rights in Islam, was not selective.

Methodology:

This research is based on documentary and library archival research. Documentary research methods include analysis of documents that contain information about the phenomenon we wish to study (Bailey, 1994). This type of research is used to investigate and categorize physical sources, namely written documents, whether in the private or public domain (Payne and Payne, 2004), such as official statistics or published research (Majdfar, F, 2003). Accordingly, this research will focus on various documents, including publications, academic papers, published interviews, official statistics and written books in the field of women's studies and gender rights. Other sources will include feminist documents published outside of Iran, mostly written by Muslim feminists working in Western academic institutions, and also documents published in national and local academic archives in Iran.

With the dominance of the empiricist and positivist perspective in the field of research methods in human sciences, researchers generally intended to collect data for their research projects through implementing surveys. Mainstream research tradition in human sciences 
in general, and social sciences in particular, emphasizes quantitative research methods. Therefore, other research methods, like documentary methods, have almost been overlooked by scientists and researchers. Most parts of textbooks on research methods belong to discussions about traditional research methods, like interviews, surveys, and participant observation, and there is little space for discussion about other research methods, like documentary and library methods (Scott 1990: 1). Indeed, the documentary research method has not generally been recognized by scientists as an accepted independent research method, which can be used as the main or principle method in a project. This method is usually used by researchers to supplement data collected from traditional research methods, like surveys and in-depth interviews. This is because it is supposed that for producing something original, the data must be new. However, we can also do an original research using old data (Hakim 1982). While traditional research methods like surveys and interviews have already been tested and have been proved as respected scientific methods, they are not the only available ones, nor are they more convenient and cost effective than other methods. Research shows that the documentary method is as good and sometimes even more cost effective than traditional research methods (Mogalakwe 2009). Indeed, the documentary method is a reliable and acceptable research method, which follows scientific rules and requires strong adherence to research ethics (Ibid).

The documentary and library method is used when a researcher intends to study past events or study the occurrence of present events he/she cannot personally eyewitness. At this time, documentary sources provide "mediate or indirect access," as opposed to "proximate or 
direct access," to the events and practices that are to be studied (Scott 1990). When you have to refer to past events or you cannot directly witness whole parts of present events you wish to study, it becomes necessary to have indirect access to those events through reviewing related documents. In contrast, proximate or direct access to the required data for research is provided mostly through implementing traditional research methods, like interviews and participant observation.

A document can be defined as an artifact, which includes an inscribed text. A document is a written text, which is produced by individuals or groups during their everyday practices (Scott 1990). It can be considered independent from its writer or the context of its production (Jary and Jary 1991). There are two kinds of documents used in the documentary and library research method: primary documents and secondary documents. Primary documents have been written by people who directly experienced an event and provided their eyewitness accounts of the event we intend to study. Secondary documents have been produced by those who did not directly experience the occurrence of events; they were not present in the scene and have received or read eyewitness accounts of an event (Bailey 1994: 194). For instance, the research studies done by Ziba Mir-Hosseini on Iranian Islamic feminism, including her interviews with traditional and neo-traditional jurists, as well as reformist scholars, are among primary documents. Studies done by Haleh Afshar, Nayereh Tohidi, Mahboobeh Sharuiat-Razavi on Islamic feminism in other Muslim countries, development of reformist discourse in Iran, the future of Islamic feminism, and Islamic perspectives toward women's issues are all among secondary sources. 
Data collected from the documentary method should be handled scientifically the same way as gathered data in other research methods. Scott (1990: 19-35) has introduced quality control criteria for handling data collected through the documentary research method. These criteria include authenticity, credibility, representativeness, and meaning. These criteria are interdependent and a researcher should regard all of them to ensure the high quality of documentary sources. Authenticity refers to whether a document has integrity, is genuine, and is of trustworthy and reliable origin. The researcher must be sure that the evidence he or she is consulting is exactly what it appears or purports to be.

Regarding the authenticity of documents in this research, I have relied on those documents that were published by dependable research institutes and organizations in and outside of Iran. For instance, I have referred to the interviews of reformists and jurists on women's issues, which have been published by reliable research centers like Islamic Propagation Office of Qom Seminaries and Kiyan magazine in Tehran. Also, I have referred to discussions about the various aspects of Islamic feminism published in dependable international academic journals, as well as reliable national academic journals, Iran.

Credibility of information refers to whether a document is free from distortion and error. The researcher must be assured that the evidence he or she is consulting is factual. He or she must be assured that the document was not intentionally altered to mislead the researcher nor was it prepared for the special benefit of the researcher. Regarding the issue of credibility in this research, I have avoided using reporters' opinions and analyses about the reformist and traditional discourse, gender relations, and women's issues published in national newspapers or broadcasted in TV programs. This is because TV programs and 
national newspapers in Iran have been accused of altering documents for their political purposes. Rather, to establish the credibility of research, I have used documents published by independent researchers and independent research institutes, which were not involved in fraudulent activities to distort information for their benefits.

Representativeness refers to whether the document that has been chosen for the research is representative of the totality of the pertinent documents. In other words, it refers to whether the consulted document is typical of its kind. This research talks about the influences of reformist discourse on the development of Islamic feminism in Iran, as well as the contention between reformist and traditional discourses on women's issues. As a representative reference of the reformist discourse, I have referred to Soroush's ${ }^{3}$ theories. His ideas of "essentials and accidentals in religion", "expansion of Prophetic experience”, "maximal and minimal religiosity", and "historical and contextual interpretation of sacred texts" have shaped the basic foundations of reformist discourse Iran. Some reformists have proposed similar ideas and some others have developed Soroush's theories within the reformist discourse. Also, Soroush's reformist ideas have been greatly used by Iranian Muslim feminists in developing Islamic feminist discourse in Iran. Iranian Muslim feminists proposed the necessity of reinterpreting sacred texts from a feminist perspective based on the new ideas developed by Soroush and his companions within the reformist discourse. Hence, Soroush's ideas can be seen as the representative of reformist discourse, which have greatly influenced the development of Islamic feminist discourse in Iran. As a

\footnotetext{
${ }^{3}$ TIME magazine proclaimed Soroush among the 100 most influential people in the world in 2005, and in 2008, Prospect magazine proclaimed him the seventh most influential intellectual in the world.
} 
representative of neo-traditionalist and traditionalist discourse, I mostly referred to Ayatollah Motahhari’s and Ayatollah Makarem Shirazi’s opinions. Mutahhari was one of the most famous Shi'a jurists in the pre-revolutionary and the early years of Islamic revolution in Iran. He mainly expressed his ideas about gender relations and women's rights in his book, The System of Women's rights in Islam, which was followed by the majority of contemporary jurists in Iran as the reference of their discussion for women's rights in Islam. Most traditional, as well as neo-traditional, jurists have accepted Mutahhari's definition and explanation of human rights in general and women's rights in particular in Islam. Also, I have referred to Ayatollah Makarem Shirazi’s ideas as a representative of traditionalist discourse on women's rights in contemporary Iran. Ayatollah Makarem has accepted Ayatollah Mutahhari’s standpoint on women's rights and gender relation. Although his opinions are mostly defined within the traditionalist discourse, which considers Islamic law eternal and immutable, he considers the possibility of modification in Islamic laws under the specific kinds of conditions. He defines three sets of conditions under which an Islamic law can be modified. Therefore, at least a few aspects of his opinions can also be classified within the neo-traditionalist discourse, which considers the possibility of change in Islamic law according to the current demands of society. On the other hand, his opinions are in line with the government's policies on women's rights and gender issues. The Islamic government of Iran defends the definition of women's right in traditionalist discourse, as opposed to its definition in the reformist discourse. 
The forth criterion in assessing the quality of a document relates to the meaning of the document. Meaning refers to whether the document is comprehensible and clear. The final purpose of investigating a document is to understand the significance and meaning of what the document contains (Scott 1990: 28). A document can have two kinds of meaning: literal or face value meaning, and interpretative meaning. In a literal understanding, the researcher only looks to the face value meaning of a text and reconstructs the significance of the text from its literal meaning. In an interpretative understanding, the researcher looks to the context from which the document was produced and reconstructs the meaning of the document by making a link between the text and its context. In other words, an interpretative meaning of a document is a product of the researcher's interpretation of the relation between the document and its contexts. Hence, one important point in using documentary sources is how to make inferences about the matters in a document through analyzing the contexts of document other than looking to the factual assertions in the document (Platt 1981). In this research, in addition to relying on the literal meaning of texts, I have interpreted the meaning of documents on women's rights within two main discourses in which discussions about women's issues have been produced. Discussions on women's rights produced by traditional jurists have been interpreted within the traditionalist discourse and discussions on gender rights, and women’s issues produced by reformist and feminist scholars have been interpreted within reformist discourse.

Moreover, occasionally, researchers combine two or more research methods in their studying of the same phenomenon in order to augment the validity and reliability of their research. This method is known as "method triangulation” (Grix 2001). For instance, they 
may enhance documentary information with in-depth interviews by those who are familiar with the phenomenon under investigation. Interviews can help a researcher to attain a more comprehensive understanding of the under-studied documents and become knowledgeable about the conflicting interpretations of the same event presented by key informants (Hakim 1987). While interviews with key informants of the Islamic feminist movement in Iran have not been conducted in this research, I have referred to interviews that have already been done with both reformists and traditional jurists regarding the status of women in Islam. These interviews have clarified the standpoint of both reformist and traditionalist discourses on women's issues.

\section{CHAPTER II: ISLAMIC FEMINISM IN IRAN}

Feminist Movements in Iran:

The Islamic revolution in Iran in 1979 changed the political structure from a secular monarchy to an Islamic government and put clergies at the top of the political hierarchy. Although at the first years of shaping the new fledgling Islamic government in Iran both 
religious and non-religious groups had their seats in Iran's legislative body in a pluralistic political circumstance, clergies gradually took control of most positions in political structure and established a national Islamic constitution at the legislative council. The Islamic Republic of Iran considered Islamic jurisprudence as the main basis of civil and social codes and compelled Iranian people to obey a set of Islamic laws. Under the name of an Islamic ideology, the government put pressure on women, through restricting their freedom and depriving them of some parts of their citizen rights (Ahmadi 2006). Afsaneh Najmabadi called these years after the Islamic revolution in Iran for women, "yeas of hardship, years of growth” (Najmabadi 1995). Although women were in a suffering situation, they always attempted and struggled to regain their rights and oppose the dominance of clergies in the past thirty years of Islamic government longevity. During these years, Iranian women with different religious, social and cultural backgrounds, whether religious or non-religious, conservative or liberal, rich or poor, educated or illiterate, tried to get back the grounds they lost through the implementation of monolithic religious policies in Iran (Moghissi 1999: 11).

Because of political pressure in Iran in the early years of the Islamic revolution, feminist activism was mostly restricted to the activities of women living abroad. Iranian secular women living outside the country tried to advocate for women's rights inside Iran. In later decades, the decrease of political pressure in Iran led the feminist movement to be followed by secular women inside the country. Both of these groups, secular activists in and outside of Iran, have tried not just to regain women's political and social rights, but also to draw the attention of the international world to the situation of Iranian women. Although these 
activities were slightly successful in publicizing Iranian women's painful circumstances to the world, they could not achieve adequate success in bringing freedom for women inside Iran as an Islamic country (Ahmadi 2006: 5-13).

One important reason for the little success of secular activism in bringing freedom for Iranian women was the barriers put forth by the government and jurists, who were commanding over all state institutions, in front of the secular activists. The Islamic government of Iran labeled secular discourse as an anti-religious and Western discourse, and barricaded its development within the Iranian religious culture. Moreover, the religious culture and social context of Iranian society did not accept secular feminist discourse as an authentic means for restoring women’s rights.

Also, secular feminism was not thoroughly successful in drawing Western feminists' attention to the condition of women in Iran because of the new wave of Islamophobia, which was spread in the world after the Islamic revolution in Iran. This trend of Islamophobia reached its climax after September eleventh, which made Western feminists not pay enough attention to women's struggles in Iran and other Islamic countries when constructing a new feminist discourse. Also, in recent decades, international concerns about the nuclear and missile program of Iran turned Iranian feminist activism to a marginal issue in international dialogues.

Therefore, it seems that a powerful religious movement from within the country was needed to be accepted by the majority of the Iranian Muslim population, and to be able to built support for women's rights. In this regard, Iranian Muslim women have struggled to start a feminist movement with the purpose of reconstructing the notion of gender within 
the Islamic discourse. Muslim feminists have tried to oppose the monolithic powerful structure and the clergy's traditional readership of Islam; they have challenged traditional interpretation of Islamic theological and legal sources to begin a new tendency in Islamic feminism (Afshar 1998).

Not only did Iranian Muslim feminists challenge the traditional interpretation of Islamic legal sources, but also they demanded more freedom in their social, economic, and political life. This resulted from feminist endeavors; not only have women not disappeared from public life after the Islamic revolution of 1979, but they also have been able to attain considerable accomplishments in various fields of industrial and educational works, artistic creation, and sports activities (Najmabadi 1995). Feminist activism has considerably developed after the presidential election of 1997, concurrent with the beginning of the reformist movement in Iran. As a result of political freedom in Iran following President Mohammad Khatami's election in 1997, we can witness an increase in the social and political presence of modern women, and a call for equal civil rights from Iranian reformists and feminist activists. Muslim women published feminist journals like Zanan and Payam-e Hajar and discussed the necessity of reinterpreting sacred texts from a feminist perspective. The development of feminist discussions in the intellectual atmosphere of Iran have stimulated theological schools in the Qom, the center of political and religious power of Shi'i clerics in Iran, to run research institutes for discussion on globalized, modern realities pertaining to women's issues. Clerics also published a journal for women entitled Payam-e Zan to explain their position on gender rights and answer questions proposed by Muslim feminists. Consequently, Muslim feminists could acquire 
the possibility of dialogue with clerics concerning Islamic jurisprudence and the issue of women's rights in Islam. During last decade, some Muslim feminists have continued their activities in collaboration with research centers affiliated with the Qom seminaries (Houzeh-ye elmie-ye Qom) and some others published their papers on gender rights in various academic journals. Mohammad Taghi Karami $(2014)^{4}$ believes that Islamic feminism has increasingly developed after 2005 in Iran. He argues that Islamic feminism had not been taken seriously as an influential discourse by Iranian feminist activists before 2005. In fact, it was during the last decade that most feminist activists have paid more attention to Islamic feminism and developed their feminist ideas within an Islamic context. ${ }^{5}$

Islamic Feminism in the Middle East:

The Islamic feminist movement was not just restricted to Iran. We can see the development of feminist movements in other Islamic countries in the Middle East. Azza M. Karam (2011: 202) classifies feminist movements in the Middle East and Arab countries into three streams in a continuum: secular (understood as a non-religious discourse), religious (largely, but not entirely, expressed in Islamic terms), and the Islamist movement (which is defending of an Islamic political ideology).

Azza M. Karam states that secular feminists generally try to represent a faith-based discourse. Some secular activists are not antagonistic toward the religion; in contrast, they

\footnotetext{
${ }^{4} \mathrm{He}$ is a faculty member of Allameh Tabatabae'i university in Tehran, Iran. He collaborates with public and private research institutes working on women's issues and gender rights. He has recently conducted research on the feminist movement in Iran, including the Islamic feminist movement.

${ }^{5}$ The viewpoint of Mohammad Taghi Karami on Islamic feminism in Iran was published on 9/17/2014, by "Mehr Khane: Paygahe khabari khanevade va zanan," (The news station for family and women), Code: 4321.
} 
are devout persons in their personal life and introduce themselves as Muslims. On the other hand, there are secular activists who do not believe in religious movements and presume religion itself as the main cause of oppression against women. These secular activists usually do not like to collaborate with their religious sisters in feminist endeavors. They believe that becoming involved in religion can create division between their ranks. Their efforts had a considerable effect on recapturing women's rights in some religious countries. However, barely, in the Middle East and Arab World, is there any admiration and verification from religious circles for those working outside of the circle, like secular activists (Ibid).

On the other side of the feminist activism continuum, there are Islamic activists. Muslim feminists in the Middle East acknowledge that women are under oppression in Islamic countries. They see Islamic reality as an appropriate option, which can release both men and women from suffering and oppression. For them, the main reason for the current injustice against women in Islamic countries is society's lack of subordination to Islam. Because Arab countries are not following God's law, we can see many problems in social, cultural, and political structures of Islamic societies. Therefore, they believe that the only way for removing the cruelty and injustice against women in Islamic countries is obeying God's law and being subordinate to Islamic rules. It is because God's order can always guarantee justice and fairness toward both men and women (Ibid 203).

There is another feminist movement in the Arab world, known as the religious feminist movement, which falls in the middle of the feminist continuum between secular and Islamic movements. Religious activists are distinguished from Islamist activists, as they do 
not advocate for any kind of political ideologies and separate themselves from the fundamentalist interpretation of religion, which some Islamic activists may advocate by following the shari'a. They support of a set of rules, which is a combination of international legal instructions and all faith traditions (Ibid).

In a comparison with the classification of feminist activism in the Arab world introduced by Karam (2011), we can classify feminist activism in Iran into two types: Islamic and secular. Since more than 98 percent of the Iranian population is Muslim (Vahedi 2010: 20), other religions remain in the minority in Iranian society. After the Islamic revolution in Iran, followers of other religions became more deprived of their citizenship rights than Muslims; they always have tried to acquire their rights as Iranian citizens. Such endeavors were implemented by men more often than women. Therefore, the feminist movement was a very marginal issue among followers of religions other than Islam, such as Jews, Christian, and Zoroastrian Iranians (Mehrangiz Kar 1993: 16).

We can witness the presence of two other sorts of feminist movements in Iran: secular and Islamic. As mentioned already, secular activists were slightly successful in drawing international attention to the situation of Iranian women. Moreover, like in the Arab world, in which there is almost no praise from religious circles for those who advocate for women's rights outside of these circles (Karam 2011: 202), we can observe a similar trend toward secular activism among the Iranian Muslim population. Religious culture and the social context of Iranian society did not consider secular feminism as an authentic means for restoring Iranian women's rights. In addition to having less popularity among the majority of the Iranian population, secular feminism has experienced much political 
pressure imposed by the Islamic government. The Islamic Republic of Iran has constantly accused secular feminist discourse of being a Western discourse, which supports Western values in contrast with Iranian religious and cultural values.

Meanwhile, Iranian Muslim women have developed a feminist discourse from within an Islamic context, under the name of Islamic feminism. This discourse has had the potential to be accepted by the majority of the Iranian Muslim population, as well as to be immune from the governmental labeling as Western and secular discourse.

Islamic feminism in Iran has considerable differences from Islamic feminism in the Arab world. Muslim feminists in Arab countries have tried to refer to the Islamic texts as the only authentic sources for emancipating women from oppression. They believe that God's law, which was articulated in the sacred texts, is just and fairly ubiquitous; and the main reason for any injustice that has been implemented against women in the Arab world is disobeying God's law (Karam 2011: 202). In this regard, Muslim feminists in the Arab world have referred to a traditional and classical interpretation of religious texts to find an appropriate solution for their problems and restore their complete rights.

On the other hand, Iranian Muslim feminists do not think that a traditional interpretation of Islamic sources can resolve the modern problems Muslim women are experiencing in their daily activities. They believe that religious texts, as well as sacred sources, require reinterpretation from a modern perspective to accommodate modern, globalized realities in Islamic countries. Accordingly, they have tried to go beyond a traditional interpretation of religious texts in order to develop a new feminist paradigm on women's issues and reconstruct Islamic notions on gender from a modern perspective. 
Islamic Feminism in Iran:

Women are calling for equal rights and participating in political structures of the Muslim world. They look for social, political, and cultural changes to improve women's situation in Islamic societies. Everywhere in Islamic countries, Muslim and secular activists, plus those who have political powers, always try to find suitable solutions for modern problems caused by the changed status of women in Muslim societies. Meanwhile, as women's issues turned to an essential element of modern Islamic discourse, a new generation of feminists was generated in Islamic countries, who named themselves Muslim feminists. Moghissi states that feminist activism has encompassed many brands, including religious and nonreligious, conservative and liberal, heterosexual and homosexual, white and non-white, individualistic and community-oriented. Hence, it seems rather superfluous to name a new brand of feminism identified by others or that self-identified as Islamic feminism (Moghissi 1999: 125).

In general, Islamic feminism can be defined as “a feminist practice and discourse expressed within an Islamic paradigm” (Bardan 2002: 17). Islamic feminism is not a specific characteristic of the West or East. It is an endeavor by Muslim women all over the world in restoring their rights, whether they are in countries with a majority Muslim population or from old established minority societies (Ibid: 3).

Maybe it is redundant to identify a new kind of feminist activism in Arab countries under the name of Islamic feminism. However, since the feminist movement, which has been developed by Muslim women in Iran, is considerably different from the feminist movements in other Islamic countries, we can categorize it as a new feminist movement 
under the name of Islamic feminism. Iranian Muslim women have looked to the notion of gender in Islam in a radical way. They have tried to present a new interpretation of sacred texts and Islamic principals in order to combat gender-biased policies and to advocate for equal legal rights. This movement of reinterpreting Islamic principles and sacred texts from a feminist perspective is unprecedented in the Islamic world. In this regard, Ziba MirHosseini remarked, "After three decades of Islamic revolution in Iran, we are now observing a growth in feminist readings of the holy texts which is unique among all Muslim countries” (Mir-Hosseini 1996: 12).

Muslim feminists in Iran believe that some parts of religious and sacred texts, especially some verses in the Qur'an, cannot be employed in the modern period; those parts of sacred texts are required to be reinterpreted from a modern perspective. Accordingly, they proposed a new feminist paradigm on women's issues, and reconstructed Islamic notions on gender from a modern perspective. The result of these feminist endeavors was a lively discussion over women's role in Islam and the development of a novel understanding of women's social, political, and spiritual status in an Islamic society. According to Esposito, Islamic feminism in Iran developed a tendency to reconsider the notion of gender in Islam in a new and radical way. He pointed out that Iran is a good case study of not just rethinking and reinterpreting Islamic legal sources, but also of reinterpreting and personally investigating sacred texts (Esposito 1998: introduction).

The principal methodology of Iranian Islamic feminism is the methodology of classical Islam. Like other Islamic thinkers, Iranian Muslim feminists try to find appropriate answers for their questions through interpreting religious and sacred texts, especially the Qur'an 
(tafsir), as well as conducting independent research in various religious sources (ijtihad). Moreover, Muslim feminists in Iran try to use methods and tools of other disciplines, such as sociology, anthropology, psychology, history, and linguistic studies, when interpreting religious texts. They also put more emphasis on their life experiences as women, which is different from that of men in their interpretation of religion. Muslim feminists, besides Western and secular feminists, confirmed that most classical and also post-classical interpretation of religious texts is only based on the male's experiences and man-centered questions. In order to reach an egalitarian interpretation of religious texts, it is necessary to reconsider those interpretations from a female perspective (Bardan 2002: 3).

Influential Factors in Developing Islamic Feminism in Iran:

One of the main factors that has helped Iranian Muslim women to develop their feminist ideas was the result of endeavors Iranian Muslim reformers made in reconsidering the traditional interpretation of sacred texts. The new perception of Islam, introduced by Abdolkarim Soroush and other Muslim scholars, has helped feminist women to present a new interpretation of gender issues in Islam. The new ideas of essentials and accidentals of history, expansion of the prophetic experience, and the historical and hermeneutic interpretation of sacred texts paved the way for feminist activists to call for the necessity of rethinking religious sources from a feminist perspective. Those women gathered in reformist circles at the Kiyan Institute ${ }^{6}$ in Tehran, and published feminist journals like Zanan, in which they discussed women's rights and gender roles in Islam. They applied

\footnotetext{
${ }^{6}$ The Kian Institute was an intellectual and cultural institute in Tehran, the capital city of Iran, in which Iranian reformists gathered around Abdolkarinm Soroush to organize their reformist activities.
} 
Soroush's ideas, as well as other reformers' opinions, to their feminist discourse and followed reformers' new approaches in interpreting religious texts. Emphasizing reformist ideas has helped Iranian Muslim feminists to integrate their faith with their feminist tendencies and has made it possible for them to develop a feminist discourse within an Islamic framework (Mir-Hosseini, 1996: 217-37).

Another factor that played an important role in expanding Iranian feminist discourse was the tendency of Iranian Muslim women to adopt postmodern ideas in their discussion of women's rights. Iranian Muslim feminists used postmodern concepts and theories to reformulate Islamic notions and law from a feminist perspective. Although it is generally agreed that any Islamic movement shows a trend toward a mediaeval Islamic period, the Islamic feminist movement is a modern movement using modern and postmodern ideas in its discourse (Amir Arjomand, 2004: 9-22). The Islamic feminist movement is barely understood as a reaction to modernity; in contrast, it is a natural consequence of reorganizing Islamic societies from a modern perspective. Iranian feminists integrated postmodern ideas and employed postmodern noetic tools like optimism, pluralism, drive for self-knowledge and the principle of diversity in their discussion. They rejected the essential nature of women as an important postmodern principle and adapted to the axiom of multiple truths, multiple realities, and multiple roles.

One of the most important features of postmodern feminism is analyzing language from a postmodern view as a complicated mechanism for institutional control. Postmodern feminism criticizes not only the structure of power in relations of domination, but also the ideological forces, which maintain these relations of domination (Butler and W. Scott 
1992; Donaldson 1992). Western feminists, using the perceptual tools of postmodern feminism, have criticized the language of monotheistic religions as being gender biased in favor of men's desires. They have claimed that theologians and jurists' biased interpretation of God represented a masculinized picture of God, which makes women inferior to men and justifies institutional oppression against women (Ahmadi 2006).

Iranian Muslim feminists employed a similar postmodern perspective in their criticism of the Arabic language as the language of Islamic sacred sources. They emphasized the function of language in creating and sustaining the relations of dominance and institutional control. They tried to expand the breadth of their interpretation of Islamic sources from a feminist perspective to a new linguistic construction of the Arabic language. This new construction of language enabled Iranian Islamic feminists to challenge the literal meaning and traditional interpretation of sacred texts. Employing postmodern critiques of language in their discussion, Iranian Muslim feminists could unveil the role of language in maintaining a gender-biased interpretation of sacred sources.

Two main sources made Iranian Muslim women familiar with postmodern concepts and theories: reformist discourse and secular feminist discourse. Iranian reformers, as well as secular feminists, have greatly used postmodern concepts in their own discussions. Iranian Muslim feminists, through connection with reformers and secular feminists, became familiar with postmodern ideas and applied these ideas in their Islamic feminist discourse. Using postmodern concepts and theories, Iranian Muslim feminists could prepare a scientific foundation for their discussion on the necessity of reinterpreting sacred texts from a feminist perspective. 
In addition to the reformist movement and postmodern ideas, the globalization of women's strides for equality and justice paved the way for Iranian Muslim feminists to develop their own feminist discourse. The processes of globalization have changed the structures of international trade, transportation, migration, communication, and information transfer through new, electronic technologies. These processes have brought multilingual and multicultural individuals who pursue various fluid identities (Giddens 1994). Indeed, the processes of globalization have made individuals and communities all over the world more integrated during past decades. This integration has made women familiar with the characteristics of feminist movements in various societies, and has strengthened the global consciousness of feminist activism on gender roles and women's rights. The processes of globalization have brought a great awareness for women of various political interpretations of women's rights, and have helped women to rethink their own society's policies and norms. According to Tohidi, "As people became aware of various political systems in the world through the processes of globalization, they are less interested in accepting their own traditional political systems and gender regimes.... Not only those who left their countries, but also those who live in their original home country are now more likely to evaluate their own lives by comparing their rights, responsibilities, and restrictions with other people in a global context.” (Tohidi 2002: 1)

In recent decades, we have been witnessing an increase of feminist activities all over the world. Feminist conferences held by the United Nations after 1975 and other similar meetings sponsored by nongovernmental organizations (NGOs) have increased cooperation among feminist activists from various societies. In this regard, after the 1995 
world conference on feminism, which was held in Beijing, a significant number of international feminist communities and women-oriented organizations and NGOs have developed their activities in Iran. These international feminist communities and organizations have put Iranian feminists in close connection with other feminist activists in Western and Muslim countries.

CHAPTER III: MAIN DISCOURSES PERTAINING TO ISLAMIC FEMINISM IN IRAN

Reformist Discourse:

Radical attitudes toward a traditional understanding of religious texts regarding women's issues, introduced by Iranian Muslim feminists, are based on the reformers' ideas about the necessity of reinterpreting Islamic sacred texts from a modern perspective. In developing their feminist discourse, Iranian Muslim feminists followed the ideas of Iranian reformist thinkers as the pioneers of reinterpretation of the Qur'an and other sacred sources. One of the most influential figures among Iranian reformists, whose ideas had considerable effects 
on feminist scholars and activists, was Abdolkarin Soroush. Soroush was introduced by Robin Wright and some other American journalist as the Martin Luther of Islam for his novel, reformist ideas about Islamic knowledge (Wright, R. 2000: 139).

Iranian reformists have gathered at the Kiyan Institute, as an intellectual and cultural institute in Tehran, around Abdolkarinm Soroush. They have published their reformist ideas about social, cultural, and political structures of Islamic societies, as well as their feminist discussions, in Kiyan magazine. Furthermore, feminist scholars gradually joined the circle of reformist intellectuals at the Kiyan institute. They employed reformist ideas, developed by Soroush and other reformers at the Kiyan Institute, in their feminist discourse and proposed the necessity of reinterpreting sacred texts regarding women's issues from a feminist perspective.

In fact, Zanan's shari'a discourse was not an abstract discourse, rather it was part of a new trend, which developed within a political and religious foundation by Iranian Muslim reformers. This novel trend, which can be best described as a post-fundamentalist discourse, was the newest debate in post-Khomeini in Iran. This debate did not challenge only the term "gender" in Shari'a, but also defied the discourse of the Islamic Republic on the condition of the political and Islamic state (Mir-Hosseini 1996: 315-16). ${ }^{7}$

Among various reformist ideas, Soroush's theories had the most influence on shaping Iranian feminist discourse. While Soroush, alongside some other reformist intellectuals in Iran, has not subscribed to the gender equality discourse, his reformist ideas on the

\footnotetext{
${ }^{7}$ Mir-Hosseini assigned a chapter in her book: "Islam and Gender: The religious Debate in Contemporary Iran" (1999) to the activities of the Kiyan institute and Soroush's discussions on gender and feminism.
} 
interpretation of sacred texts and Islamic knowledge have enabled Iranian religious women to attune their faith with their feminist ideas. Soroush developed his reformist ideas in various disciplines, including theology, philosophy, sociology, and history of religion, as well as in gender studies and feminism. Soroush, against most of other Iranian reformers, was able to organize his reformist ideas in the form of coherent theories. These coherent theories were greatly used by Iranian women in shaping the underlying philosophy of Islamic feminist discourse Iran. Indeed, Soroush's reformist theories stimulated Iranian Muslim feminists to discuss of women's rights in Islam and propose the necessity of reinterpretation of sacred text from a feminist perspective. In this regard, I refer to MirHosseini, who mentioned the influences of Soroush's ideas on feminist discourse.

"I did not have any bright idea about how Soroush stimulated feminist women in Zanan. After I read his book about the essential and accidental in religion, I found that I have to shift my focus. Actually, it was not just his idea about gender that inspired women in Zanan, but also it was his new approach to the interpretation of sacred texts and his new conceptualization of Islam that authorized women to discuss gender equality. By now, I can see how his new interpretation of sacred texts opened up a new space for radical reformism in gender subjects, among other issues.” (Mir-Hosseini 1996: 238)

Soroush's new ideas on the theology of Islam, the hermeneutic interpretation of the prophet's tradition, and the philosophy of Islamic law and shari'a have influenced Iranian Muslim scholars, especially those working in Zanan. One of his most influential reformist 
ideas that shaped Iranian Islamic feminism was his discussion about the meaning of “essential” and "accidental” in Islam.

Soroush argued that, on the one hand, there are essential parts (zati) in the Qur'an, which are unchangeable and ever-lasting. These parts are the main foundations of Islam. Without them, Islam is no longer Islam. On the other hand, there are some parts in the Qur'an that were shaped by the society and time in which the prophet was born and raised. He called those parts accidentals (arazi) (Soroush 1989: 4-19).

Soroush described his criterion in separating essential parts from accidental parts in the Qur'an: the history of Islam is contingent as all other histories. My criterion in separating essential from accidental is based on this knowledge about things that could have happened in other ways. For example, the principle of oneness and uniqueness of God (tawheed) is an essential part of the Qur'an because it could not have happened otherwise and without it, Islam is not actually Islam. However, it was an accidental of history that Muhammad was born in Arabia and therefore the language of the Qur'an became the Arabic language, which shaped the main conceptual framework of the Qur'an (Soroush 1999: 21).

Soroush argued that because the prophet was Arab, his usage of notion and words in transferring God's word to the people was confined to Arabic culture and language. Therefore, if the prophet had been born in another place besides Arabia, such as Greece or Iran, his language and also his way of thinking would be different. In addition, if he had been born in a place other than Arabia, Qur'anic rules on social subjects would be different and hence the Qur'an would be a different book in some parts, in those which are accidentals. Therefore, the Qur'an is a product of a certain place and certain time. To 
support his argument, he referred to the verses of the Qur'an to show how the issues of some parts of the Qur'an would be completely different if the language of the Qur'an was not Arabic or the prophet had lived somewhere besides Arabia (Soroush 1989, 4-19). In his opinion, all of the events that have taken place in the history of Islam, which could have happened in other ways, are accidentals. These parts must not be included in the domain of faith (Soroush 2009: 89).

To have access to the core message of religion, a believer should engage in a cultural translation of past events that happened in the early years of Revelation, to the present time. A believer's ijtihad should be the historical translation of linguistic, socio-cultural, political, and economic circumstances from past to present. This historical translation is necessary for each Muslim to distinguish accidental from essential parts of religion.

In other words, Muslims should differentiate "historical Islam” from the "spirit of Islam". Soroush mentioned fourteen items that can help us in reconstructing historical Islam; these fourteen items give a clue to distinguish the accidentals from essentials in sacred sources:

"Religion does not have an Aristotelian essence or nature; it is the Prophet who has certain goals. These goals are religion's essentials. In order to express and attain these intentions and to have them understood, the Prophet seeks the assistance of (1) a particular language, (2) particular concepts and (3) particular methods (fiqh and ethics). All of this occurs in a particular (4) time and (5) place (geographical and cultural) and for (6) a particular people with specific physical and mental capacities. 
The purveyor of religion is faced with specific (7) reactions and (8) questions and, in response to them, gives (9) specific answers. The flow of religion over the course of time in turn gives rise to events, moving some people to (10) acquiesce and others to (11) repudiate. Believers and unbelievers fall into (12) particular relationships with each other and religion; they fight battles or create civilizations, (13) engage in comprehending and expanding religious ideas and experiences or (14) wrecking and undermining them" (Soroush 2009:90-1).

Therefore, the historical events that happened in the early years of Revelation within a specific time and place, the prophet's particular language, method, and concepts used for transferring religion's essentials to other people, as well as religious ideas about social orders, are all additions to the essential parts of religion, and must be translated to the present. Soroush argued that those who ignore the historian and contextual background of the Qur'an and other sacred texts in their interpretation turns soon to autocrats who believe that the shari' $a$ and Islamic laws are unchangeable (Soroush 2000: 220). Rather, Soroush believes that shari'a is silent and its representatives give the voice to it; shari'a does not provide invariable answers for all historical problems (Soroush 1995, 34).

In another reformist idea, known as the "expansion of Prophetic experience," Soroush provided examples from the Qur'an to prove that the prophet's living experience was humanistic like other Muslims' living experiences. He concluded that the prophet was a human like others, so his experience was humanistic. This humanistic experience was expanded throughout history by other Muslims. In this regard, he provided examples of how the prophet's disciples expanded his religious experience in the history and developed Islamic knowledge (Soroush 1999: 21). Soroush referred to the speaking of Jalal al-Din 
Muhammad Balkhi, known as Rumi, one of the most famous Islamic Sufis in the thirteenth century, to show how the prophet's experience has expanded during the history of Islam.

According to Rumi, revelation (wahy) did not stop with the death of the prophet. It was not just the prophet who received revelation; rather, Sufis have also received various kinds of revelation from the God. While Rumi believes that Sufis have also received revelation, he does not consider them as prophets because they do not have specific responsibilities and duties that God only put on the shoulders of prophets.

Soroush argued that Sufis have added to Islamic knowledge and practices. For instance, he said that Rumi added other forms of prayers like sa' $m a^{8}$ to the traditional forms of worships in Islam. Soroush considered masnavi ${ }^{9}$ as a supplementary to the Qur'an, and said that Rumi added the notion of love to the Islamic literature. Soroush argued that Rumi defined the relationship of humans and God in a new form of lover-beloved relationship. This kind of relationship between the God and His creatures was not defined in the Qur'an. Rather, the Qur'an defined the relationship of God and believers based on hope and fear: hope to God's mercy and fear of God's punishment. ${ }^{10}$

\footnotetext{
${ }^{8} \mathrm{Sa}$ 'ma literally means "listening" and is considered as a Sufi ceremony performed as $d h i k r$ (remembrance of the names of God). Sa'ma is a kind of worship, which often includes playing instruments, singing, recitation of the names of God, dancing, recitation of poetry, wearing symbolic attires and other rituals.

${ }^{9}$ Masnavi, or masnavi-I ma'navi, is an extensive spiritual poem written by Rumi, mostly in Persian. It consists of six books, which are known as one of the most influential sources in Islamic Sufism and mysticism. In this document, Rumi explains how to reach to the goal of being in true love with God. He discovers various aspects of lover-beloved mysticism and its spiritual joy.

${ }^{10}$ Siamak Dehghanpour did this interview with Abdolkarim Soroush under the subject of "Mawlawi and the Persian Qur'an”. This interview was broadcasted by Voice of America on 05/10/2014 http://ir.voanews.com/media/all/horizon/latest.html?z=1566
} 
Based on this explanation, Islamic knowledge is not just restricted to what was stated in the sacred texts. The prophet's disciples and other Muslims like Sufis have added to this knowledge during the history of Islam. In extracting Islamic laws, we should also take into account that other documents have been added to the Islamic primary sources. Hence, Islamic laws are not immutable, since they are not only based on what was stated in the Qur'an and Sunna.

We can witness similar reformist ideas about the interpretation of religious texts, which have been developed by other Iranian Muslim reformers at the Kiyan institute. For instance, Alireza Alavitabar expanded Soroush's theory about the accidentals of history to a vast degree, which covered most parts of the Qur'an; he said that not only Arabic language and culture, but also scientific happenings, historical events, and many stories in the Qur'an and the prophet's tradition, lay in the realm of accidentals and do not apply to this time (Alavitabar, A. 2003). Said Amir Arjomand stated that there was not just the entire body of sacred law as an accidental part of the Qur'an; also, the culture that has been extended around it should be considered as an historically contingent figure of sacred texts (Amir Arjomand 2002: 719-21). Regarding the historical and contextual interpretation of sacred texts, Malekian argued that we should look to the Qur'an and Sunna from an historical perspective. We should ask what the prophet wanted to do with the help of the Qur'an and Sunna in the specific historical and social circumstances of the early years of Islam. We should be aware of the main reasons behind his behaviors (Malekian 2000).

Indeed, reformist discourse, which has been developed by Islamic intellectuals in Iran, represents a modern behavior that intends to reconcile feminism, democracy, and other 
modern elements with Islamic faith. Not only Muslim intellectuals, but also some eminent clerics have called for Islamic reformation (Tohidi 2006: 628). These clergies, as well as Iranian reformers, have demanded reformulating Islamic concepts from a modern perspective and substituting traditionalist jurisprudence (fiqh-e sunnati) with dynamic jurisprudence (fiqh-e pouya) (Ibid). For instance, Saeed-zadeh confirmed that we should think of modifying the current system of fiqh to prevent obvious oppressions against women. Islamic laws on the right for divorce, the right for custody, and polygamy should be reviewed (Saeed zadeh, 1997). Some of these clergies collaborated with reformers at the Kiyan Institute and were active in Kiyan magazine, as well as in feminist journals like Zanan and Payam-e Hajar.

Reformist theories regarding the contextual and historical interpretation of sacred texts, the expansion of prophetic experience, and the essentials and accidentals of history, paved the way for Iranian Muslim feminists to demand a reformation in interpreting religious texts from a feminist perspective. Based on these theories, they have argued that those verses in the Qur'an that reflect some experiences of Arabic culture and Mohammed's personal life were just specific to an historical time in the early years of Islam and are not applicable to the modern time.

In this regard, Muslim feminists, through independent personal investigation of sacred texts (ijtihad), have identified many Islamic laws in gender issues as accidentals in Islam, instead of their current interpretation of being fundamentals in the Iranian legal constitution. Muslim feminists have provided examples of Islamic laws as specific to the Arab culture and the prophet's society. Such rules include the law allowing Muslim men to marry four 
women, the conditions of temporary marriage in Islam, and those rules that give automatic rights of divorce to men (Ahmadi 2006). For instance, Kazemi declared that polygamy was prevalent in pre-Islamic Arab society. Islam was not able to resist this tradition and remove it completely. Hence, in order to support women's rights, Islam put limitations on polygamy and changed its conditions. Indeed, polygamy was imposed on Islam by the Arab culture in the early years of Islam. Now, the social condition has changed. We are now aware that polygamy produces many problems and disrupts family relationships. Therefore, polygamy is not permissible at this time (Kazemi 2002).

While Iranian Muslim women made endeavors in demonstrating gender-biased aspects of Islamic laws, their voices have not considerably been heard by traditional jurists. Women are still excluded from interpreting religious and sacred sources. One of the main reasons for this exclusion is the dominance of patriarchal ideology over the thinking mode of traditional jurists that left little space for women to take part in discussions for extracting shari'a ideals from sacred texts. Moreover, traditional jurists did not consider feminist women as experts in Islamic knowledge. Hence, they did not accept feminist women’s interpretation of Islamic sources as an authentic and reliable interpretation. However, traditional jurists could not challenge the new interpretation of Islamic sources on women's issues that was introduced by male reformers. They did not mostly accuse reformers as less educated in Islamic knowledge, since most reformist intellectuals and clergies have already studied Islamic sciences in academics, as well as in traditional schools in Qom seminaries (Houzeh-ye elmie-ye Qom). Therefore, reformers were more successful than Iranian 
Muslim women in presenting the modern interpretation of religious texts on women's issues and gender rights.

\section{Traditionalist Discourse:}

The objective of Iranian Islamist feminism is the pursuit of equality and justice in Islamic law on gender issues (Lorestani 2003). Iranian Islamist feminists challenge traditional jurists by presenting new discourses underlying Islamic legal thought. These discourses can be divided into two types: neo-traditionalist and reformist. Indeed, we can distinguish three discourses underlying Islamic legal thought Iran. The first is the discourse of classical fiqh text, known as traditionalist discourse. Traditionalist discourse was developed by jurists on the basis of biological differences between men and women. This discourse reflects circumstances of the society in which traditional jurists had lived. In that society, inequality between men and women was seen as the natural order of things. Patriarchal structure in that society shaped the world-view of classical jurists in their understanding of sacred texts.

Gender relations are based on women's duties in traditionalist discourse. According to MirHosseini, in classical fiqh texts, women are seen as sexual beings, not as social beings; the only domain in which women's rights are partly discussed is family law (Mir-Hosseini 2003).

The influence of the patriarchal structure on classical jurists can be best seen in their interpretation of the marriage contract, which defines women as subject to the male authority. In classical fiqh text, the logical structure underlying the marriage contract is 
similar to the sale contract. The man pays a dower (Mahr) to the woman to have access to her sexual and reproductive faculties. Although classical fiqh resembles marriage to the sale just in the form not in the spirit, it is the logic of the sale contract that underlies the classical fiqh conception of women's rights. That is, classical jurists define the main purpose of marriage as gratification of sexual needs and procreation (Abd Al Ati 1997); they see women's sexuality as a commodity, as a subject of the marriage contract. While there are both moral and legal obligations incumbent on each spouse in the marriage, moral obligations are unenforceable and marginal to legal obligations, those injunctions based on the rules of sale.

Fuqaha, ${ }^{11}$ claim that they derive the ideal model of gender relations, particularly in marriage, from sacred sources. The influence of the patriarchal structure on the thinking modes of classical jurists, as well as the exclusion of women from producing religious knowledge, are two main reasons for the classical interpretation of sacred texts. The patriarchal ideology, which was an inalienable part of jurists' lives, left little space for women to take part in discussions for extracting shari'a ideals from sacred texts. The women's voice is more marginalized in the political life of Muslim society as long as we move further from the years of Revelation (for more review, see Ahmed, 1992, chapter 4: “The Transitional Age”). Under the influence of patriarchal ideology, jurists created a gender-biased philosophical foundation underlying their traditional interpretation of sacred texts and Islamic legal thought.

\footnotetext{
${ }^{11}$ Fuqaha' are Muslim jurists responsible for the development of fiqh, as an Islamic science with its own specific legal theories and methodology, over the course of centuries.
} 
Indeed, the epistemological and philosophical foundation of classical legal thought, which defines women's status as a fixed and unchangeable issue in fiqh law, is the main reason for unequal gender relations embedded in traditionalist discourse. Fiqh rulings on gender rights are based on a set of philosophical and metaphysical assumptions like "women are created of and for men," or "God gave women greater sexual desire than men which should be controlled by men." Using these assumptions, fugaha' made women subjugated to men in marriage and other fiqh rulings regarding gender relations. Defining marriage in a form of sale contract provides a juristic basis for women's subjugation to men. In this regard, fugaha' granted more freedom to men and set more restrictions for women in marriage rules. For instance, the Islamic law of marriage permits men to enter more than one marriage (up to four) at a time, as well as to abolish the marriage contract at will without the wife's consent.

Classical jurists not only looked at marriage as a social or private contract (mu'amala), but also considered it as a ritual/spiritual act (ibadat). Indeed, they did not want to lower the status of women to a commodity; rather, they considered women as humans. In this regard, in addition to defining the legal form of marriage in the form of a social contract (mu'amala), they talked about marriage as an act of worship. It is considered in figh that those rulings that lie in the realms of ibadat, which regulate relations between God and humans, are immutable and constant, and those rulings which are in the domain of mu'amala, which regulate relations between humans, are changeable and subject to rational explanation. However, classical jurists treated marriage rules and other rulings pertinent to gender relations, even those in the domain of mu'amala, as immutable and limited to the 
scope of rationalization. They did not define gender relations and women's status as social and cultural terms; rather, as divinely ordained subjects based on revelation (wahy), which has permanent validity and is not subject to change in response to social and political forces.

In fact, in the Qur'an, women's status is not treated as a divinely ordained issue, but as a changeable social practice (Mir-Hosseini 2003). However, Muslim jurists, rather than embodying shari'a ideals in fiqh rules, created God's law according to their ideal model of family and gender relations, as a permanent Divine Justice (Sachedina 1999a:29). The philosophical and metaphysical assumptions underlying fiqh laws cannot be supported by sacred texts; they are contrary to the voice of revelation (wahy) and Qur'anic objectives of bringing justice and fairness for both genders (Wadud 1999, Mernissi 1991, Hassan 1987). Muslim scholars concluded that these assumptions are rooted in the patriarchal structure of pre-Islamic Arabia, which continued to the Islamic era (Ahmed 1992, Mernissi 1991).

Neo-traditionalist Discourse:

Another discourse underlying Islamic legal thought in Iran is the neo-traditionalist or modern discourse. Neo-traditionalist discourse was started in last decades of the nineteenth century and was more developed in the early years of twentieth century. This discourse is known as the modern discourse in Islamic legal codes. The encounter of modern nationstates with waves of modernity changed gender roles and women's status in Islamic countries. Neo-traditional jurists tried to find a solution for modern problems emerged in Islamic countries because of the changed status of women. Their aspiration for creating gender equality in Islamic law is not based on the Western discourse; rather, it is based on 
the demand of Muslim women for freedom and justice in their everyday lives in the twentieth century.

On the one hand, neo-traditionalists tried to resist the emergence of Western values and lifestyles, which was supported by secular elites in Islamic countries. On the other hand, they wanted to support gender equality and accommodation of traditional fiqh rules with the modern discourses on women's status and gender roles. The result of their efforts was arguing for gender equality in some parts of Islamic laws and rejecting reformation in some others (for more review see, Mir-Hosseini 1999, Mutahhari 1991, Siddiqi 1952).

In order to defend the fiqh notion of gender, as well as support equality in gender rights, neo-traditionalists changed the assumptions and theories underlying classical fiqh texts, and defended of the theory of "naturalness of shari'a law." ${ }^{2}$ For instance, they did not accept this classical assumption that "women were created of and for men.” Instead, they declared that both men and women were created equally and each can attain perfection independently; women are not dependent on men to attain perfection and salvation. However, men and women should have different roles in their lives since they have different rights and duties. In other words, while neo-traditionalist changed some genderbiased assumptions underlying classical fiqh text, they defended the fiqh model of gender relations since they believed that this model is in line with human nature.

\footnotetext{
${ }^{12}$ The theory of naturalness of shari'a law was first introduced by Allameh Tabataba'i, a famous shi'a philosopher, in pre-revolutionary Iran, in his Qur'anic commentary known as Al-mizan. This theory was developed by his student Murtaza Mutahhari as the philosophical foundation of shari'a law.
} 
They believed that both men and women are equal in the eyes of God, but this equality does not mean that both genders should have equal rights and duties. Since men and women have biological differences, they were assigned different rights and duties. This difference in rights and duties does not mean inequality or injustice; rather, it is the very essence of justice, which was reflected in fiqh rules.

In this regard, jurists, in their defense of the fiqh notion of women's rights, tried to reform traditional assumptions underlying classical fiqh rules. They proposed the notion of complementarity of gender rights and duties and the theory of the naturalness of shari'a law. In their endeavor to modify the gender biased assumptions underlying traditional fiqh texts, neo-traditionalists looked to Western sources like sociological and psychological sources to prepare scientific evidence for their argument. However, their usage of scientific sources was selective and they just used those modern theories that were in line with the fiqh definition of gender relations.

To better clarify the standpoint of neo-traditional jurists on women's status and gender relations in Islam, I refer to the ideas of Ayatollah Murtaza Mutahhari, one of the most famous Shi'a jurists in contemporary Iran. Mutahhari’s ideas, which were expressed in his book, The System of Women's rights in Islam, have been followed by the majority of contemporary jurists in Iran as the reference of their discussion for women's rights in Islam. Most neo-traditional jurists have accepted Mutahhari's definition and explanation of human rights in general and women's rights in particular in Islam. Hence, his interpretation of women's rights can be used as the representative of the interpretation of women's rights in neo-traditionalist discourse. 
Not only do neo-traditionalists follow Mutahhari's explanation of women's rights, but also traditional jurists who are responsible for making Islamic law in contemporary Iran have admitted to following his opinions. Therefore, his opinions about the Islamic definition of gender roles and women's rights have been accepted by both traditional and neo-traditional jurists. His argument is based on the theory of the naturalness of shari'a law, which considers fiqh rules in line with human nature (fitra). Mutahhari does not accept the assumption that "women were created of and for men"; however, he believes that nature separately has granted a certain kind of characteristic to men and women, which cannot be exchanged. According to the separate dispositions granted by nature, men and women hold different rights and are responsible for different duties in their lives. In this regard, he considers women's sexuality subordinate to men's sexuality as a consequence of gender differences in emotional dispositions and moral issues:

"Under the command of creation, every man and woman has a certain disposition and certain characteristics, when compared with each other, which cannot be exchanged and are not the same. ... Nature has devised the ties of husband and wife in such a form that the part of woman is to respond to the love of man. The affection and love of a woman that is genuine and stable can only be that love which is born as a reaction to the affection and admiration of man towards her. So the attachment of the woman to the man is the result of the attachment of the man to the woman and depends upon it. Nature has given the key of love of both sides to the man, the husband. If he loves his wife and is faithful to her, the wife also loves him and remains faithful to him. It is admitted that women are naturally more 
faithful than men, and that a woman's unfaithfulness is a reaction to the unfaithfulness of the man.” (Mutahhari 1991: 297 and 274)

Mutahhari did not change or modify the body of classical fiqh rules on marriage and gender relations; instead, he presented a new rationalization for classical Islamic laws. For instance, he stated that the right to divorce should remain in the hand of men because the law of Nature has granted this right to men:

"Nature has deposited the key of the natural dissolution of marriage in the custody of man. In other words, it is a man who by his own apathy and unfaithfulness towards her wife makes her cold and unfaithful. Conversely, if the indifference begins on the side of the wife, it does not affect the affection of the man, rather, incidentally, it makes the affection more acute.” (Ibid: 297)

If the fiqh rules on gender relations and women's rights are based on the natural differences between both genders, then these rules remain everlasting, which cannot be changed in various social, cultural, and political circumstances. Natural differences are defined as biologic and inborn emotional differences, which are constant ubiquitously. Indeed, rationalization of Islamic laws according to the natural differences between men and women distances these laws from the influences of time and society. While neotraditionalists changed the gender-biased assumptions underlying classical fiqh texts, they did not make considerable changes in the form of classical fiqh rules. For instance, they accentuated emotional and moral aspects of marriage, and did not look to marriage as a model of sale contract the same as classical jurists. However, their conclusion of Islamic laws on marriage was the same as that of traditional jurists. In other words, what neo- 
traditional jurists did was provide a new justification for gender-biased Islamic laws on gender roles and women's rights.

Definition of Women's rights and Gender Roles in Traditionalist Discourse:

While neo-traditional jurists, alongside traditionalists, changed the form of some parts of fiqh rules on gender issues, they have mostly remained faithful to the classical interpretation of fiqh texts. They have tried to prepare a new explanation and rationalization for definitions of fiqh on women's rights. In this regard, they have followed of Mutahhari's ideas in the rationalization of Islamic legal thought. Not only have neo-traditional jurists followed Mutahhari's ideas on women's rights in Islam, but also traditional jurists applied his theories in their arguments for gender roles and women's rights in Islam. To better clarify the standpoint of traditionalist discourse on women's rights, I refer to the ideas of Ayatollah Makarem Shirazi, as one of the most influential jurists in making Islamic law in Iran. Present traditional jurists usually refer to his theories in their discussions on women's issues. Moreover, his opinions are in line with the policies of the Islamic Republic of Iran on women's rights and gender roles. It is true that the ideas of Ayatollah Makarem Shirazi are representative of traditionalist discourse in contemporary Iran. However, his ideas can also be discussed within neo-traditionalist discourse. He believes in neo-traditional assumptions underlying Islamic law, like the theory of the naturalness of shari'a law, which was proposed by Ayatollah Mutahhari. Moreover, he believes that jurists should take into account the modern realities of Muslim society, as well as the results of modern science, in making Islamic law. 
Ayatollah Makarem Shirazi classifies various theories on gender differences into three groups and describes Islamic worldview on gender differences:

"There are three distinct theories about the differences between men and women. The first theory doesn't consider any difference between men and women. According to this theory, we shall accept that all men and women are equal in all aspects of their lives. However, this theory isn't compatible with scientific rules and the reality of life. Those, specifically Westerns, who support this theory in their argument on gender differences, disregard equality between both genders in their practical lives.

The second theory considers the status of men higher than women's. This theory believes in gender differences and considers men as the first gender and women as the second gender. Men's rights are accepted and women's rights are denied in this theory.

Both of these theories are incorrect since they don't rely on the real differences between men and women. The correct perspective on gender differences, which is the Islamic perspective, says that men and women have different responsibilities in their lives according to their different physical and mental characteristics. To better understand the differences between men and women's responsibilities, the status of men and women in the society can be assimilated to the status of mind and heart in the body. We cannot say that heart has higher status than mind in the body. Each of those parts has separate vital responsibilities in the body. In fact, without each of these parts, the body fails to survive. 
Therefore, by paying attention to the real differences between men and women, Islamic laws on gender issues are easy to follow and understand.” (Tahura journal: 2008) $)^{13}$

Ayatollah Makarem Shirazi assimilates society to the human body, and the role of men and women in a society to the role of heart and mind in a body. Mind and heart have separate responsibilities in a body and the whole function of a body depends on the function of them, respectively. While the proper function of these two parts is essential for the proper function of the body, neither of them can replace the other's responsibilities.

To better clarify his ideas about the naturalness of differences in gender roles, Ayatollah Makarem Shirazi provides examples of social roles, which are done by men and women, respectively:

“There are many works in a society that are classified as harsh works. We believe that since women are more sensitive than men, these harsh works are not compatible with their emotional characteristics. Therefore, these works are appropriate for men. For instance, commanding a brigade is a harsh work, which is suitable for men, not women, as well as being the pirate of a warplane. A pirate needs to know skydiving and other hard skills. In every place in the world, these works are done by men.” (Ibid)

In the same way, he provides an example of fiqh rules on differences in gender roles:

\footnotetext{
${ }^{13}$ Pajuheshgah olum ensani va motaleate farhangi, (Human science and cultural studies institute) arranged this interview with Ayatollah Makarem Shirazi, and published his opinions on women's rights in Tahura journal, portal jame olum ensani, on 87/1/12, 03/31/2008.
} 
"Judgment is also considered as a harsh and rough job, where a judge sometimes sentences the death penalty for a culprit, whipping for a condemned person, or taking away all of a theft's belongings. It is stated in Islam that a woman's sensitiveness and soft-heartedness is not in line with harsh judgment environment.

However, women can receive many other roles in the society that have higher status than judgment and are more suitable for them.” (Ibid)

Therefore, Ayatollah Makarem Shirazi distinguishes different roles for men and women according to their different physical and emotional characteristics. Moreover, he confirms that there always are exceptions among men and women in physical and metaphysical characteristics. For instance, he states that maybe there is a woman who is less sensitive than men and is able to do the harsh works. However, a ruler does not have to pay attention to the exceptions in making a law. A ruler always considers characteristics of the majority of population in creating laws; he cannot make a rule according to the characteristics of the minority or the exceptions. Therefore, a ruler always makes a law according to the characteristics of the majority of the population. In all places in the world, rulers disregard characteristics of the exceptions in creating laws. Ayatollah Makarem Shirazi explains that this methodology used in making law is based on the principle of hikmah ${ }^{14}$. According to the principle of hikmah, a ruler always tries to make a law compatible with the characteristics of the majority of population. This law must be obeyed by the whole of

\footnotetext{
${ }^{14}$ The literal meaning of hikmah is wisdom in Arabic. Hikmah, or wisdom, is the application of the right knowledge at the right time to a specific issue. Hikmah is to know as the best of things by way of the best of sciences. This term can be associated with all matters of human life. In other words, there is not any limitation to the application of hikmah in every aspect of our lives.
} 
population, even by the exceptions that their characteristics are not similar to the characteristics of the majority. The principle of hikmah also applies in making Islamic law. For instance, he provides examples of Islamic laws on women's rights, in which the jurists pay attention to the characteristics of the majority of the population and disregard specific characteristics of minorities:

"In Islam, the heritage for men is twice women's heritage. It is because in Islamic worldview, men are responsible for the whole expenses of the family; they have to cover the expenses of home, clothing, the wife's dower, medicine, etc. A man has to satisfy the whole of his wife's and his children's needs. He is the only one responsible for meeting the family costs. ${ }^{15}$

Therefore, since a man has more economic responsibility than a woman in the family, his heritage is twice that of a woman. Some people say that there are families in which women are responsible for the expenses of the family. In some families, men are unemployed and women are the breadwinner and economic supporter of the family. Therefore, in such families, women's heritage must be the same as or twice men's heritage. We (jurists) reply to these people that if we want to consider these exceptions in making laws, there will always be challenges in the law of heritage. A ruler cannot easily distinguish whether a woman has more or less responsibility in her family. A ruler cannot make a rule for these exceptions. Hence,

\footnotetext{
${ }^{15}$ This interpretation of Islamic worldview regarding the assignment of economic responsibilities in the family had also been articulated by Murtaza Mutahhari (for instance, see "the system of women's rights in Islam": 78).
} 
according to the principle of hikmah, we should look to the characteristics of the majority of population. In most cases, men are the breadwinner and are responsible for the expenses of family. Therefore, their heritage was determined to be twice women’s.” (Ibid)

He also provides another example of Islamic laws on men's and women's rights to show the naturalness of shari'a law:

“According to the principle of hikmah in Islamic law, men's diyeh ${ }^{16}$ is twice that of women's. The reason for this difference is that the death of husband in a family will cause more economic pressure for that family than the death of wife. Since a man is responsible for the expenses of his family, his death will bring more economic pressure for his family than the death of his wife. Some people say that the difference in the amount of diyeh shows that there is a difference in Islam between the price of men's and women's blood. This explanation is not true, since killing a man or a woman has the same punishment in the God's eyes. Difference in men's and women's diyeh is related to the economic issues. Again, since a ruler looks to the characteristics of the majority, he considers men, not women, as the main supporters of the expenses of families. Therefore, men's diyeh should be twice that of women's.” (Ibid)

\footnotetext{
${ }^{16}$ Diyeh is an Arabic term, which means ransom or blood money. According to Islamic law, diyeh is the financial recompense is given to the victim or the heirs of a victim in the cases of murder, the loss of body parts, or the damage of property. This punishment is an alternative to the punishment of Qisas (equal retaliation) in Islamic jurisprudence.
} 
As we can see, Ayatollah Makarem Shirazi tries to rationalize the differences in Islamic laws on gender issues. He confirms that this difference in Islamic laws on gender issues is based on the natural differences between men and women. Men and women play different roles in a society and, according to their natural and inborn characteristics, they have different duties and responsibilities in their family and society. Therefore, Islamic laws must be based on these differences and hence, must be different for men and women. While he confirms that Islamic laws for men and women are different, he does not believe that these laws are always constant and everlasting. He states that there are two kinds of Islamic laws: constant laws and variable laws. Indeed, according to specific kinds of principles, an Islamic law can change during history. He declares that an Islamic law can be modified if one of these three conditions happens:

1- The change in the subject of an Islamic law: according to a general Islamic principle, we can buy or sell everything that has a considerable $\mathrm{Halal}^{17}$ benefit. Perhaps buying and selling one thing in the past time was not permissible according to Islamic laws since that thing did not have any considerable benefit. However, buying and selling of that thing is permissible right now since now it has a considerable Halal benefit. For instance, human’s blood did not have Halal benefit in the past. Now, however, it has a Halal benefit. Blood transfusion can save a person's live. Therefore, buying and selling a human's blood is now permissible according to Islamic laws. Also, animals' blood is now used for the nutrition of

\footnotetext{
${ }^{17} \mathrm{Halal}$ is every object or action that is allowed to use or engage according to Islamic law. Haram is every object or action that is forbidden to use or engage according to Islamic law. The terms Halal and Haram cover all items of daily life.
} 
some other animals. Therefore, buying and selling animals' blood is also permissible since it has Halal benefits. One other example in this regard is the buying and selling of humans' organs to the sick people who need those organs to live. In these cases, we can see the change in Islamic laws as the subject of that law that has changed.

2- A new scientific discovery: In this condition, the subject of an Islamic law has not changed. Instead, the results of a new scientific discovery have caused the change in an Islamic law. For instance, it was thought in the past that using tobacco did not have detriments for the health. Therefore, most of Ulama used to smoke cigarettes or the hookah. However, now, according to the latest medical discoveries, it has been proven that using tobacco can cause dangerous illnesses. Therefore, the result of this medical discovery has caused a change in Islamic law on using tobacco. Indeed, since jurists did not know that using tobacco had several detriments for humans' health, they permitted using tobacco. Now, though, using tobacco is not permissible according to Islamic law, since its detriment for health has been proven by recent medical research.

3- The coincidence of a second title on the subject of an Islamic law: Sometimes, with the passage of time, a second title is attached to an Islamic law, which causes the change of that law. For instance, in Islam, the right of divorce was completely in the hands of men. In recent times, divorce conditions have changed and women can also repudiate their marriage under specific conditions. In present times, if men have the right to divorce without the supervision of court, women will be deprived 
of their rights because men are free to repudiate marriage without any logical reason.

In the past, the divorce rate was very low and men did not repudiate marriage without logical reasons, but in recent years, they have misused their right for divorce. Therefore, the change of conditions caused a change in Islamic law of divorce. In other words, a second title has been attached to the Islamic law of divorce.

In recent years, women can repudiate marriage through two options: first, they can include their desired demands in the marriage contract, which must be satisfied by their husband. If their husband does not pay attention to those demands, the woman can repudiate marriage. Second: a woman can argue to an Islamic court that she is in the status of usar wa haraj ${ }^{18}$. When an Islamic court finds that a woman is really in usar wa haraj, it will command the husband to satisfy his wife's needs. If again the husband does not pay attention to the court's commands, Islamic court will repudiate their marriage according to the women's request without her husband's consent (Ibid).

According to Ayatollah Makarem Shirazi, if each of the above conditions happens, an Islamic law on women's issues will change. Again, he confirms that a change in an Islamic law can only happen if the characteristics of the subject of an Islamic law have changed. On the other hand, if the subject of a law has not changed, the law will remain unchanged. This is because what the prophet declared Halal will remain Halal and

\footnotetext{
${ }^{18}$ Usar wa haraj is a concept in Islamic fiqh, which means the continuation of marriage will cause the woman harm and hardship.
} 
what he declared Haram will remain Haram until the doomsday. He claims that if we act according to this methodology, many problems on women's issues will be solved. However, he cautions that we should not join the international women's convention because joining this convention is not useful for women. We should act according to traditional figh texts, which regulate every aspect of our lives (Ibid).

\section{CHAPTER IV: DISCUSSION}

Discussion and Conclusion:

Since one of the main purposes of the Islamic revolution in Iran was to return to the ideals of shari'a, after the Islamic revolution, the Iranian Islamic state translated the fiqh notion of gender into the state policy. In the early years of the Islamic state, jurists responsible for legislating civil laws followed traditional readership of fiqh texts and created the Islamic constitution on the basis of the classical fiqh definition of gender. Because of the support of the majority of the Iranian population of the Islamic revolution and its ideals, traditional jurists were not required to provide any explanation or rationalization for the Islamic laws on women's issues in the early years of revolution. 
After one decade of the establishment of the Islamic state, Iranian feminist and reformist activists questioned gender-biased aspects of Islamic laws. Decrease of political pressure inside Iran after the presidential election in 1997 provided this opportunity for reformist and feminist activists to develop a new discourse on gender based on modern and Western values. With the emergence of reformist discourse and the expansion of reformist and feminist activism, a new generation of Iranian jurists, known as neo-traditional or modern jurists, tried to provide a rational explanation for their traditional readership of classical fiqh texts.

Different factors caused the development of Islamic feminist discourse in Iran. The processes of globalization, which made Iranian Muslim feminists connected to Western and non-Muslim feminist activists, the activities of secular feminists, and the expansion of modern and postmodern ideas on gender roles and human rights in the intellectual atmosphere of Iran were all influential on the development of Iranian Islamic feminism. Among all of these factors, it was the reformist movement that had the most influence on the development of Iranian feminism. Indeed, the new approach in the interpretation of Islamic laws and sacred texts expanded in the reformist discourse was greatly used by Iranian Muslim feminists in the development their Islamic feminist discourse.

Iranian Muslim feminists' activism, as well as reformists' endeavors in challenging philosophical foundations of fiqh rulings made not only neo-traditional but also traditional jurists reconsider Islamic laws on gender issues. Another factor that pushed jurists to rethink fiqh rules on gender issues was the influence of Western values and modern lifestyles on the Iranian family structure. The entrance of Western values has changed the 
lifestyles of Iranian people and the structure of the Iranian family. Increased presence of women in higher education and workplaces, increased rate of divorce and single-parent families, the prevalence of pre-marital sexual relationships, increased presence of women in the political structure, and the development of women's social activism are all among the realities of Iranian women's lives in recent decades. These factors stimulated traditional and neo-traditional jurists to accommodate classical fiqh texts with the modern realities of Iranian society.

In this regard, they have changed gender-biased assumptions underlying classical fiqh texts, as well as those parts of Islamic law which are not in line with women's rights. While neo-traditional jurists, alongside traditionalists, changed the form of some parts of fiqh rules on gender issues, they have mostly remained faithful to the classical interpretation of fiqh texts. Indeed, they have tried to prepare a new explanation and rationalization for the definitions of fiqh on women's rights.

According to the neo-traditionalist viewpoint, Islamic laws must be different for men and women, and only with this difference will justice toward both genders be served. The philosophy of Islamic laws is based on the theory of complementarity of gender rights and duties. Men and women have different responsibilities and duties in a society, and hence, different rules must regulate their lives. Neo-traditionalists believe that Islam is a religion of fairness, which brings justice for everyone. This justice is only guaranteed if there are gender differences in Islamic law. In other words, they believe that Islamic law is fair toward both genders, but this fairness does not mean proportional equality. To rationalize their understanding of gender differences in Islamic law, they provide various explanations. 
On the one hand, they advocate for the theory of naturalness of shari'a law, which states that fiqh rules are in line with human nature (fitra). They say that from a biological perspective, women and men have some natural and inborn differences that demand different considerations regarding their rights and duties.

For instance, Ayatollah Murtaza Mutahhari says that in Islam, the right for divorce is in the custody of men because nature has granted this right to men. He believes that naturally, if unfaithfulness begins on the side of a man, it makes his wife cold and unfaithful. Rather, if the indifference begins on the side of a woman, it makes her husband's affection more acute. Hence, this is a man who can make his wife cold and indifferent through showing apathy toward her, and therefore can dissolute the marriage. If a woman shows this indifference toward her husband, the result would be reversed since the woman's indifference will increase the man's affection and will strengthen the romantic relationship. He continues that it is admitted that naturally, women are more faithful than men and their unfaithfulness is a reaction to men's unfaithfulness (Mutahhari, 1991: 297 and 274). This explanation is based on the theory of naturalness of shari'a law.

On the other hand, neo-traditionalists provide scientific explanations for their genderbiased readership of figh texts. They claim that Islamic laws on gender issues are also compatible with scientific theories. In this regard, Ayatollah Murtaza mutahhari provides examples from Western sources in sociology and psychology to rationalize assumptions underlying classical fiqh texts. He does not accept previous gender-biased assumptions underlying classical fiqh texts introduced by traditional jurists, like the assumption that “women are created of and for men.” Instead, he provides other assumptions, which are 
based on natural and biological differences between men and women. He believes that these assumptions are also supported by scientific results. However, his usage of scientific theories, in supporting assumptions underlying fiqh rules, is selective. He uses those parts of scientific theories that are parallel with the fiqh definition of gender and avoids using those parts of modern science that contradict with the definition of gender relations in classical fiqh texts in his argument.

He says that Islam has done a great service to women. It has recognized women's natural rights and has given them independence, freedom, and personality. However, there are differences between the steps taken by Islam and the West toward women's issues. One of these differences is about the psychology of men and women. He believes that Islam has done and revealed a great wonder in the field of psychology of men and women, which is different in some angles from that of Western psychology (Mutahhari 1999: 13).

Indeed, his usage of psychological sciences is selective; to support his argument on women's rights, he refers to those parts of modern sciences that are consistent with the psychology of men and women presented by Islam. He refers to the ideas of those Western scientists who believed in natural differences between males and females. For instance, he mentions the ideas of Alexis Carrel, a French psychologist and biologist, who believed that according to the law of creation, men and women have been created differently, and because of these natural differences, they must have different rights and obligations (Ibid: 53). Carrel believed that differences between men and women are not just related to differences in the shape of their genital organs, or the female's capacity to give birth to children. It emerges from the differences in chemicals, which genital glands secrete into 
the blood. Organic and psychological differences between men and women require them to advance in two dissimilar directions. We should not visualize for women the same kind of aspirations and ideals, the same kind of life, and the same way of thinking as we visualize for men (Ibid).

Mutahhari provides a similar explanation of the biological differences between males and females to that of another psychologist, professor Reek. He says that professor Reek, who has done extensive research about the affairs of men and women, also confirms that men and women have two different bodies, which are not similar in composition. They do not act or feel similarly, nor do they have similar reactions to various incidents. Indeed, they belong to two different worlds (Ibid: 57).

Mutahhari states that in the modern world, the more medical, social, and psychological studies are done, the bigger disparities between men and women are discovered. According to the results of modern science, it is now obvious that the world of men is different from that of women in many respects (Ibid: 56).

This trend of using scientific theories to rationalize gender-biased aspects of Islamic laws has been followed by contemporary traditional jurists. In addition, it seems that present traditional jurists even put more weight on the role of recent discoveries of modern sciences in their analysis of fiqh texts. Not only do they try to find a scientific basis for classical fiqh rules, but they also consider a possibility of changing in those parts of Islamic laws that are not supported by scientific results. 
Ayatollah Makarem Shirazi says that an Islamic law can be modified if it is not supported by science. He provides an example of using tobacco, which was permissible in the past time since it was thought that using tobacco did not have any detriment to the health. However, using tobacco is not permissible right now according to Islamic law, since it has been proven by the science that it is harmful for the health. It seems that Ayatollah Makarem Shirazi relies on the findings of medical sciences. However, his opinion about the findings of human sciences is not as clear as his opinion about the findings of medical sciences.

While the important parts of the assumptions underlying fiqh rules, like the assumptions of women's sexuality, are mostly discussed in human sciences, it is not clear to what extent traditional jurists rely on the findings of human sciences on these issues. For instance, both Shi'a and Sunni jurists believe that God gave women greater sexual desire than men. Hence, women's sexual desire must be controlled by men (Mir-Hosseini 2003). If it is proven by the results of psychological and sociological research that women's sexual desire is not greater than men's, then men will not be responsible for controlling women's sexuality and women are not to be subjugated to men. However, it is not obvious whether traditional jurists accept such findings of human sciences in the field of gender relations and women's sexuality as authentic scientific rules. We cannot say whether they change their assumptions underlying fiqh rules according to the results of modern science.

On the other hand, traditionalists, like neo-traditional jurists, mostly assign differences in male and female sexuality to the natural and inborn differences between both genders, which were designed by God. To support their argument, they only use those parts of 
scientific theories that are in line with their definition of human sexuality and gender roles. Indeed, their usage of the theories of human sciences is selective, the same as the neotraditionalists' method in reference to human sciences. They advocate for the theory of naturalness of shari'a law. According to this theory, differences in male and female sexuality, as well as differences in gender roles, remain constant and unchangeable during time.

Therefore, it is hard to say that traditionalists will rely on the findings of human sciences on gender issues and women's rights in the same way that they have relied on the findings of medical science. Indeed, there is a pessimistic perspective among traditional and neotraditional jurists toward human sciences, as they believe that these sciences are not in line with people's religious beliefs. It seems that with the existence of this pessimistic attitude toward Western human sciences among governmental figures, as well as traditional and neo-traditional jurists, especially in the recent years, it is unlikely that the findings of Western human sciences will have considerable effects on traditionalist discourse underlying Islamic laws.

In addition to considering the possibility of change in Islamic law according to the findings of modern science, Ayatollah Makarem Shirazi considers another possibility of change in Islamic law according to the change in social conditions of the society. He says that an Islamic law can be changed when a second title coincides on its subject. His example in this regard is the right for divorce, which was completely in the custody of men. However, in recent times, divorce conditions have changed and women can also repudiate their marriage under a specific set of conditions. He says that because in recent times, men have 
repudiated the marriage contract without any logical reason, Islamic law of divorce has changed to limit men's freedom in repudiating the marriage contract and to restore women's rights. Therefore, the change in the contemporary social conditions has caused the change in the Islamic law of divorce.

While he supports the change in the Islamic law for divorce, he does not believe in the necessity of modifying the Islamic laws of heritage and diyeh. He provides a rationalization for gender differences in the Islamic laws of heritage and diyeh. He explains that a man is responsible for all of the expenses of his family; a man has to satisfy all of his wife's and children's needs. Therefore, since a man has more economic responsibility than a woman in a family, his heritage must be twice that of a woman. In the same way, he explains that since a man is responsible for the expenses of the family, his death will cause more economic pressure on his family than the death of his wife. Therefore, men's diyeh must also be twice that of women's. He continues that there are families in which men are unemployed and women are responsible for the expenses of the family. However, these families are in the minority and jurists cannot pay attention to the characteristics of minorities in making laws.

According to this explanation, the question is that if a considerable change happens in social conditions in which women will have more economic responsibilities than men in their families, will the Islamic laws on heritage and diyeh be modified? Traditional jurists’ answer to this question is obscure. On the one hand, they say that jurists look to the characteristics of the majority of the population in making laws. Hence, we expect that if in most families women have more economic responsibility than men, then their heritage 
will be twice or at least the same as men's. On the other hand, Ayatollah Makarem Shirazi says that in Islam, men are responsible for the expenses of their family. He believes that according to Islamic teachings, a man has to satisfy all of his wife's and his children's needs. With this explanation, we expect that the change in social and economic conditions of a society does not provide any change in men's responsibilities in supporting the economic needs of their families. Hence, the Islamic law of men's heritage will remain unchangeable under different social and economic conditions.

Therefore, it seems that traditionalists' attention to the results of modern science and their attention to the change of social conditions in modifying Islamic law are selective. While they believe that the change in social conditions and the results of modern science are both influential in modifying Islamic laws, they do not apply this rule to all parts of fiqh rules. Traditionalists did not clearly specify which differences between men and women are inborn and natural and which differences are the products of specific social conditions. Meanwhile, they have provided a rationalization for gender differences in the majority of fiqh rules according to the theory of "naturalness of shari'a law," and have modified only a few parts of fiqh rules according to the changes in social conditions or the results of modern sciences. It is because they believe that most parts of classical fiqh rules are everlasting; only a few parts of these rules require modifications in order to be employed in modern times. Therefore, while they have tried to change traditional gender-biased assumptions underlying Islamic laws, they have not changed most parts of these laws regarding gender issues. 
Moreover, traditionalist discourse confirms that classical fiqh texts can regulate every aspect of our lives. We can find a solution for every problem and an appropriate answer for all questions we have in our lives in fiqh texts. Therefore, traditional jurists define gender relations, women's rights, and all aspects of women's sexuality within an Islamic context. This philosophy of interpreting Islamic sources is different from the reformists' philosophy.

Indeed, both reformist and traditional thinkers believe that Islam is a religion of fairness and justice. They both see in the shari'a equality for both genders, however they reach different conclusions in applying Islamic laws from the shari'a. Reformists and traditionalists believe in women's rights, but they define them in two different ways. While neo-traditional and traditional jurists believe that gender differences in Islamic law bring justice for both males and females, reformists believe that justice and fairness toward both genders can only be acquired through proportional equality.

These differences between reformists' and traditionalists' standpoint on women's issues are based on their different philosophy in interpreting Islamic sources. Reformists, in contrast to traditional and neo-traditional jurists, consider a distinction between religion and religious knowledge. They believe that the objective part of religion, which is the revealed text, is different from religious knowledge, or the interpretation of that revealed text. While the objective side of religion (the revealed text) is sacred, holy, and immutable, religious knowledge is always subject to evolution. In this regard, reformists believe that all aspects of our understanding and interpretation of sacred texts, including fiqh rules, rest in the domain of religious knowledge and are subject to modification. On the other side, 
traditionalists consider their own understanding of sacred texts, which is represented in fiqh rules, as holy and fixed as the sacred texts themselves. Indeed, by differentiating between these two concepts (religion and religious knowledge), reformists' and traditionalists' standpoints on shari'a ideals and fiqh rules can better be understood.

Traditionalists believe that Islam has regulations for every aspect of our lives, and we can find an appropriate answer for all of our questions in Islamic sources. Therefore, to define women's sexuality and gender relations, they refer to the definition of classical fiqh texts on these issues. They think that women's sexuality and gender relations were ordained Divinely, and hence are sacred and unchangeable. Rather, reformists see women's sexuality as regulated by social circumstances and not by Divine will. Reformists claim gender inequality embedded in Islamic laws as a societal construction by male jurists that is neither sacred nor fixed, and rather is human and subject to contestation.

Not only do traditional and neo-traditional jurists define gender roles and women's issues within as Islamic context, but they also believe that Islam has a clear opinion about all other aspects of human life. In contrast to this readership of Islamic sources in traditionalist discourse, reformist discourse considers other responsibilities for religion. Reformists believe that religions and Islam in particular do not have any responsibility to regulate all aspects of human lives. They state that all parts of sacred texts should not be used as unchangeable sources in making Islamic laws, since those parts are just compatible with the social conditions of the early years of Islam.

In this regard, Abdolkarim Soroush distinguishes between the essential parts and accidental parts of the sacred texts. He argues that there are essential parts (zati) in the Qur'an, which 
are unchangeable and everlasting. These parts are the main foundations of Islam; without them Islam is no longer Islam. On the other hand, there are some other parts in the Qur'an as a result of the society and time in which the prophet was born and raised. He calls those parts as accidental (arazi). (Soroush 1989: 4-19). Although he does not separate essential parts from accidentals in every verse of sacred texts, he provides a criterion in separating essential parts from accidentals in the Qur'an: this criterion is based on this knowledge about things that could have happened in other ways. For example, the principle of oneness and uniqueness of God (tawheed) is an essential part of the Qur'an because it cannot have happened otherwise and without it, Islam is not actually Islam. However, it was an accidental of history that Muhammad was born in Arabia and therefore the language of the Qur'an became Arabic language, which shaped the main conceptual framework of the Qur'an (Soroush 1999: 21).

He believes that most historical events that happened in the years of revelation rest in the domain of accidentals. In order to have access to the core message of the religion, which he calls essentials, we should translate historical events from past to present. In other words, we should differentiate between "historical Islam" and "the spirit of Islam". In this regard, he refers to various items that can help us in reconstructing "historical Islam". These items are additions to the sacred texts and are known as accidentals in his argument. For instance, he says that the particular language, particular concepts, and particular methods the prophet used to transfer the essence of religion to the people, as well as some questions and answers transmitted between the prophet and other Muslims, are among accidentals. 
With this criterion, most parts of social rules on women's issues rest in the realm of accidentals, since they could have happened in other ways if the prophet lived in other societies or in other times. Also, most parts of sacred texts are accidentals; just a limited part of these texts are essentials. In line with this explanation, Alireza Alavitabar said that not only the Arabic language and culture, but also scientific stories, historical events, and many stories in the Qur'an and the prophet's tradition, lie in the realm of accidentals and do not apply to this time (Alavitabar 2003).

Reformers believe that the purpose of Islam was to talk about and accentuate the essential parts. Accidental parts are just related to the society and time in which the prophet was born and lived:

“God's revelation is like a muse, an "inspiration” for poets, and Muhammad transmitted this "inspiration," in the language he knows, and the style his people understand, to reveal the essentials of the new religion of Islam, without doing without the accidentals, i.e. the socio-cultural circumstances that bound both the prophet and his community. If Muhammad lived in a different context, time and space, revelation could have been translated differently, but its core message would have been the same."19

Hence, according to the reformist discourse, the essential parts of sacred texts reveal the core message of Islam, which is permanent; the accidental parts are additions to the sacred

\footnotetext{
${ }^{19}$ This is a part of Michel Hoebik's interview with Dr. Soroush on December 2007 under the name of "The word of Muhammad”. http://www.drsoroush.com/English/Interviews/E-INTThe\%20Word\%20of\%20Mohammad.html.
} 
texts that a believer in Islam must understand according to various contexts and circumstances. The accidental parts are fallible; in other words they are open to change according to various contexts.

Soroush further proposed the notion of "minimalist religiosity" against the notion of "maximalist religiosity" as a supplemental commentary to "the theory of essential and accidentals in religion.” Soroush believes that religion does not say everything and believers should not expect too much of religion (Hashas, 2014). He has a minimalist perspective toward the elements of religion, like fiqh and ethics. He considers ethical values as objective, minimalist, accidental, and this-worldly (secular). He further continues that "fiqh is incomplete; it is perfect in terms or precepts (theory), and not in planning; it is minimalist, and not maximalist; it is not religion” (Soroush 2009: 100-1). Believers seek perfection and salvation in religion. They generally wish to find everything in religion. In other words, they look at religion as a maximal reservoir and source in which they can find appropriate answers for every question in their lives. However, it is not the purpose of religion to talk about everything. The main purpose of religion, according to the reformist perspective, is to talk about essentials. In fact, Islam has some rules regulating believers' social lives. However, we should draw attention to the fact that these social rules are not maximal. Also, those rules should be modified to be employed in the present time. In the case of fiqh law, Soroush says that classical jurists extract maximums from minimums. They have changed fiqh rules to a final verdict regulating every aspect of believers’ lives, instead of making minimums adjustable to various circumstances and changeable according to the spirit of religion (Soroush 2009: 94-97). 
It is because traditional jurists' orientation toward religion, shari' $a$, and ethics is otherworldly. The otherworldly view considers the rationale behind the Islamic law a Divine rationale or a Divine secret. This viewpoint sees Islamic laws as duties with the purpose of producing felicity in the hereafter. It loses the spirit of religion and focuses on the ultimate consequences of Islamic laws in the hereafter. Therefore, otherworldly oriented religion severs ties with the problems emerge from social affairs. It emphasizes believers' duties, which have been assigned by Divine order and are reflected in Islamic laws.

On the other side, reformists try to generally consider religion and shari' $a$ this-worldly, and not otherworldly. They try to make a link between the shari' $a$ and this world. In thisworldly perspective, the rationale behind the Islamic laws is not a secret Devine rationale, rather it is believers' social affairs and society's needs. In this worldview, the main purpose of fiqh rules is to run social affairs and solve problems that emerge from them. Islamic laws are judged according to their immediate, and not ultimate, consequences.

From the reformist perspective, Islamic laws are in general based on human rights, and not on human duties. Since Islamic laws are judged according to their immediate consequences, they are constantly subject to change and contestation. If they cannot satisfy believers' needs, they have to be modified. This is the meaning of the historical translation of accidentals from the past to present. Islamic rules, which have regulated believers' lives in the history of Islam, are accidentals of religion. They are not based on Divine order; instead are this-worldly and based on social order. Hence, they need to be modified constantly according to the present social affairs and current people's needs. According to 
this explanation, reformist discourse, in contrast to traditionalist discourse, not only defines gender roles, gender relations, and women's rights out of the religious context, but also constantly modifies its definitions according to the changes in social conditions.

However, reformists and feminists do not play a considerable role in making Islamic law in Iran. Extracting Islamic law from sacred texts is only in the hand of traditional jurists. It does not seem that traditionalists will include reformists in extracting Islamic law from sacred texts. Therefore, it is only the philosophy and epistemology of traditionalist discourse which defines assumptions underlying Islamic law Iran. In order to reach gender equality in Islamic law, the philosophy and epistemology of traditionalist discourse on gender relations and women's rights should be modified.

To modify the philosophy of traditionalist discourse, jurists should adopt a minimalist perspective toward the elements of religion, including figh and shari'a. Traditionalists should not expect classical fiqh texts to regulate every aspect of human life. If traditional jurists' orientation toward fiqh texts is minimal, most aspects of human life, including women's issues, can be defined out of the religious context. Following the minimalist perspective, jurists can rely on the findings of medical sciences, as well as human sciences in defining women's sexuality, gender relations, and gender roles. Moreover, if the majority of women's issues are defined out of the Islamic context, the orientation toward these issues will be secular and this-worldly. From this-worldly perspective, Islamic laws are judged according to their immediate consequences, based on believers' social affairs and society's needs. This-worldly perspective toward fiqh and shari'a opens more space for human rights and provides gender equality in Islamic laws. 


\section{LIST OF REFERENCES:}

Afshar, Haleh. 1998. Islam and Feminisms, an Iranian Case Study. London: MacMillan.

Ahmadi, Fereshteh. 2006. Islamic Feminism in Iran and West-oriented Ideas. Women and Fundamentalism, 6:5-13.

Ahmed, Leila. 1992. Women and Gender in Islam: Historical Roots of a Modern Debate. New Haven: Yale University Press.

Bahrami, Fatemeh, and Etemadi, Ozra. 2013. Roshde Tahsilate Zanan dar Iran be Onvane Olgoo-e Zanane Mosalman (Development of women's education in Iran). In Strategic Thought, Woman and Family, 36-44.

Bailey, Kenneth. 1994. Methods of social research. $4^{\mathrm{TH}}$ edn. New York: The Free Press.

Butler, Judith and Scott, Joan W. 1992. Feminists Theorize the Political. New York: Routledge.

Esposito, John. 1982. Women in Muslim Family Law. New York: Syracuse University Press.

Grix, Jonathan. 2001. Demystifying Postgraduate Research. Birmingham: Birmingham University Press.

Hakim, Catherine. 1982. Secondary Analysis in Social Research, A Guide to Data Sources and Methods with Examples. Boston: Allen and Unwin.

Hashas, Mohammed. 2014. Abdolkarim Soroush: The Neo-Mu'tazilite that Buries Classical Islamic Political Theology in Defense of Religious Democracy and Pluralism. Studia Islamica 109: 147-173.

Karam, Azza. M. 2011. Feminism in Islamic countries. In The Oxford Handbook of Feminist Theology, ed. McClintock M. Fulkerson, and Sheila Briggs. Oxford: Oxford University Press. Ch 8.

Kazemi, Shokoufeh. 2006. Ta'adode zojat dar ghanoone Iran (Polygamy in Iranian civil law). Tehran: Tose'e publication 3.

Laura E. Donaldson. 1992. Decolonizing Feminisms: Race, Gender and Empire Building. London: Routledge. 
Lorestani, Fariborz. 2003. Jonbeshe Ejtemae-e Zanane Iran” (social movement of Iranian women). Zanan Research Quarterly 1: 23-42.

Majdfar, Fatemeh. 2003. Jame-e Shenasi Omoomi (General Sociology). Tehran: Sho'a publication.

Malekian, Mustafa. 2000. Eslam, Feminism, va Mardsalari” (Islam, Feminism, and Patriarchy), Zanan 64.

Mir-Hosseini, Ziba. 1996. Stretching the Limits: A Feminist Reading of the Shari' $a$ in postKhomeini Iran. In Feminism and Islam: Legal and Literary Perspectives, ed. M. Yamani. London: Garnet.

- 1998, Rethinking Gender: Discussion with Ulama in Iran. Critique: Critical Middle Eastern Studies. 7: 45-59.

- 1999. Islam and Gender: The Religious Debate in Contemporary Iran. Princeton NJ: Princeton University Press.

—. 2002. The Conservative-reformist Conflict over Women's Rights in Iran. International Journal of Politics, Culture, and Society. 16. No 1.

- 2003. The construction of Gender in Islamic Legal Thought and Strategies for Reform. London: Brill NV, Leiden.

Moghissi, Hedieh, 1999. Feminism and Islamic Fundamentalism: The limits of postmodern analysis. London: Zed Books.

Motemassek, Reza. 2001. Femenist Eslamic, Vagheiat ha va Chalesh ha” (Islamic Feminism, Realities and Challenges). Collections of Publications in the Conference about Investigation on Women's Problems, Priorities and Approaches. vol 1.

Mutahhari, Murtaza. 1991. The Rights of Women in Islam. $4^{\text {th }}$ edn. Tehran: World organization for Islamic services.

Najmabadi, Afsaneh. 1995. Feminism in an Islamic Republic: Years of Hardship, Years of Growth. In Islam, gender, and social change. Kankash. no 12.

Payne, Geoff, and Payne, Judy. 2004. Key Concepts in Social Research. London: Sage Publications.

Scott, John. 1990. A matter of Record, Documentary Sources in Social Research. Cambridge: Polity Press.

Shahidian, Hamed. 1998. Femenist Islami va Jonbesh-e Iran (Islamic Feminism and Iranian Movement). Iran name. Published in America.

Soroush, Abdolkarim. 1989. Zati va Arazi dar Din (Essential and accidental in religion). Kian, no 8. 
- 1995. The Theoretical Construction and Expansion of the Shari'a. Tehran: Sirat publication.

— 1999. Bast-e Tajrubeh Nabavi (Expansion of Prophetic Experience). Tehran: Sirat publication.

—. 2000. Siasat Nameh (Political letters), Tehran, Sirat publication.

- 1999. Bast-e Tajrubeh Nabavi: Maghalat-i dar Tarikh-geraee, Peivastegi, va Takasorgaraee dar Din (Expansion of Prophetic Experience: Essays on Historicity, Contingency and Plurality in Religion. English translation by Nilou Mobasser, and Forough Jahanbakhsh. 2009. Leiden: Brill.

Tohidi, Nayereh. 2002. The Global-local Intersection of Feminism in Muslim societies: The Cases of Iran and Azarbaijan. Social Research. 69: 3.

—. 2006. Islamic Feminism: Negotiating Patriarchy and Modernity in Iran. In The Blackwell Companion to Contemporary Islamic Thought, ed. Abu Rabi, Ibrahim M. Blackwell publishing. Ch 35: 624-44,

Vehedi, Meisam. 2010. Human Development in Iran and Its Correlation with People's Relihious and Political Values. Master Thesis of Sociology in the Social Science Faculty of the University of Tehran. Tehran. 